\title{
A Philosophy of Intellectual Property (1)
}

Peter DRAHOS

山根 崇邦(訳)

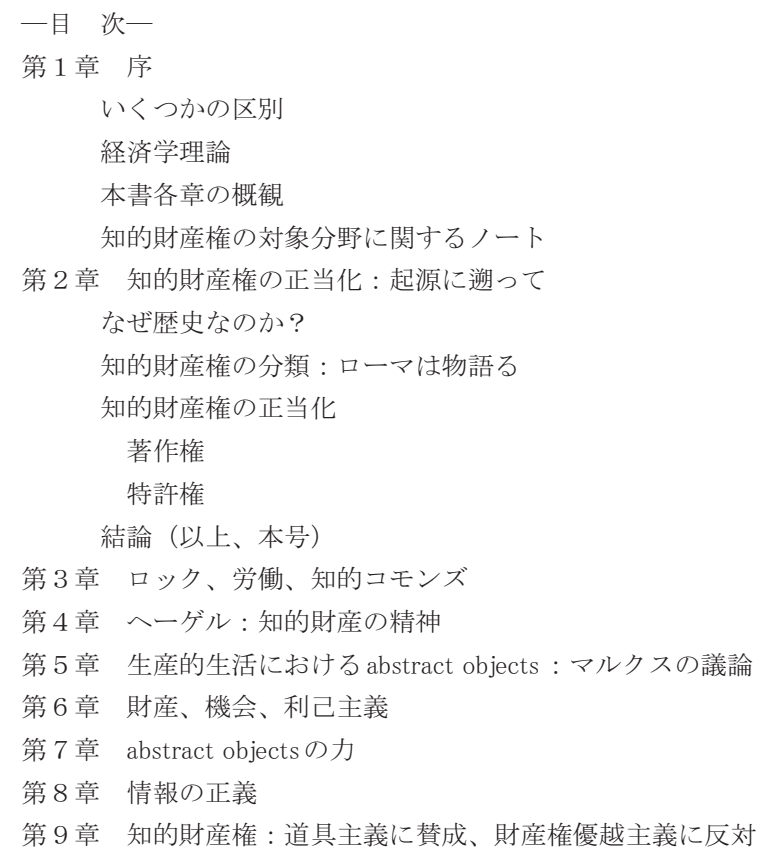

\section{第 1 章 序}

所有理論（the theory of property）に関しては、これまで数多くの著作が書 き表されている。所有はこれまで、そして今なお、社会科学理論について の根本的なテーマの 1 つとなっている。その権利の形式 (つまり、所有と 
は権利の束であるという考え方 $\left.{ }^{1}\right)$ において、所有は哲学的分析の主要な 対象であり続ける。所有に関する文献は膨大な数にのぼるが、知的財産に ついて明示的に論じたものは比較的少ない。もしか寸ると、所有の一般理 論が知的財産権を含むあらゆる所有形態を明らかにするということが前 提とされているのかもしれない。この前提はおそらく正しいし、またおそ らく正しくない。他の財産権 (property rights) と同じく、知的財産権は私 人間の関係を規律するものである。しかし不動産法と異なり、知的財産法 は権利を abstract objects（抽象的対象、無体物）に措定する。アルゴリズ ムやペニシリンの製法およびその派生物は abstract objects の具体例である。 多くの人々が abstract objects を必要とし、利用をし、依存をしている。現 代の「オン・ライン」社会における社会生活や事業を特徵づける相互依存 関係の多くが、そのような abstract objects と結びついている。重要な abstract objects の私的支配を許容寸る所有形態は、とりわけ社会において 多くの人的依存関係を生みだす。それは私的権力の膨張をもたらす。個人 の消極的自由、つまり干涉されない権利はますます大きな危険に直面する。 所有がその範囲を abstract objects にまで拡大寸るとき、多くのことが危機 にさらされる。これらの理由から、少なくとも次のことを問うことには価 值があるように思われる。それは寸なわち、我々は所有に関する既存の 1 つまたは複数の一般的な説明の枠内で知的財産を受容することができる のか、それとも我々は知的財産特有の理論を発展させなければならないの かということである。

本書はこの問いに対する解答の端緒を提示するものである。本書では、 ロック、ヘーゲル、マルクスという、所有に関寸る三人の重要な思想家の 著作を取り上げる。そして結論として、驚くことではないが、我々が知的 財産の現象について理解するうえでこれらの著作は非常に有益なもので

1 権利の束という財産観は、ケビン・グレイ(Kevin Gray)の次のような一節が上手 く捉えている。いわく、「私が領空の一部を販売する場合、肝心なことは、希薄な 大気の分子を別にすれば、そこには絶対的に何も (nothing) 存在しないということ である。もちろん重要なことは、私はあなたに物ではなく『権利の束』(a bundle of rights) を譲渡したのであり、『権利の束』こそが財産を構成するということである。」 K. Gray, 'Property in Thin Air', 50 Cambridge Law Journal, 252, 259 (1991).
あるということを提示する。本書では包括的な知的財産理論の提示は行わ ない。その代わりに最終章では、道具主義という哲学的姿勢が知的財産に 関する学際的アプローチや理論枠組みを構築するうえで指針となるべき ことを主張する。とりわけこのことは、知的財産権の場合には、特権 (privilege) という用語が財産権という既存の用語に取って代わるべきで あるということを意味する。義務を帯びた特権こそが知的財産理論の中核 をな寸べきであるというのが、本書の最終章の主張である。

\section{いくつかの区別}

リベラルな系譜における所有理論の構築は、通常、財産権理論の構築と いう形をとることが多かった。このように所有を一種の権利として取り扱 うことは、権利の一般理論と所有理論との大きな相互作用を生みだすこと が予想される。そしてそのことは、はたしてあらゆる権利は財産権である のかという問いんと我々を誘うのである2。権利基底的な所有理論に属す る研究がその権利の範囲および対象の境界を定めるために典型的に用い るいくつかの区別が存在する。そうした区別の種類というのは、存在論的 アプローチ、言語学的アプローチ、分析的（ないし概念的）アプローチ、 および規範的アプローチ間での区別である。我々は現在の取組みがこれら の区別との関連でどこに位置するのかについて、ここで簡単にでも何かい っておく必要がある。しかし、まずは当該区別自体について一言述べるこ とにする。

存在論的分析は、権利は存在するか否か、存在するとすればどのような 方法で存在するのかという問題に焦点を当てる。自然権や自然権的財産権 の存在をめぐる論争は、存在論的問題の具体例である。言語学的アプロー チとは、通常の言語使用においてみられる意味や区別を参照することで、 所有や権利の意味を確定しようと試みる手法のことである3。限られた紙 幅の中で言語学的アプローチと分析的アプローチとの区別を行うことは

2 こうした議論については、G.F. Gaus, 'Property, Rights, and Freedom', 11 Social Philosophy and Politics, 209, 211-216 (1994) 参照。

${ }^{3}$ A. Reeve, Property (London, 1986), 10-12. 
困難である4。ごく大まかにいえば、分析的アプローチとは、資料として の通常の言語に自らを閉じこめることなく、理性および確立された推論技 法という制約のもとで、特別に規定された多様な区別や概念モデルを検討 の用に供することを提案し構築するものと概括することが許されよう。分 析的アプローチは、所有や権利のような概念の論理的な性質に焦点を当て る傾向がある。そうした分析的アプローチは、定義および概念分析のプロ セスを通じて、よりよい概念モデルや概念の構造的かつ関係的理解を得よ うと努める。分析的に取り組む場合、哲学者は、誰が権利をもつことがで きるのか、そしてそれはどのような条件の下においてかといった質問を行 う。例えば、哲学者は、権利をもつということは何であるのかということ と、どのような権利を我々は承認すべきかということとの区別を描きだそ うとする。所有や権利の分野において大きな影響力をもつ分析的アプロー チの例は、権利 (right)、義務 (duty)、特権 (privilege)、無権利 (no-right) といった相互に説明可能な概念間の、法的相関項の集合 (a set of jural correlatives）としての、つまり矛盾項 (contradictories) および相関項の矛盾 項の集合としての、ホーフェルド（Hohfeld）の権利モデルである ${ }^{5}$ 。（我々 は第 7 章においてその体系と知的財産権へのインプリケーションについ て論じる予定である。）最後に、所有理論や権利論における規範的アプロ 一チは、何らかの結論に到達するために、あれこれと多様な価値を利用す る。規範的アプローチは処方箋あるいは正当化と関係している。つまり行 為のルールが提案されるか、あるいは擁護されるのである。

規範的所有理論の大半が私的所有権の正当化可能性の検証に焦点を当 ててきた ${ }^{6}$ この特定の取組みへの強い関心は、単に現代においてみられる

${ }^{4}$ その理由の 1 つは、そうした区別を行おうとする試みが直ちに哲学的分析それ自 体の性質問題を生みだすからである。この問題に関する文献として、R. Rorty (ed.), The Linguistic Turn (Chicago, London, 1967) を参照。

${ }^{5}$ W.N. Hohfeld, Fundamental Legal Conceptions (Westport, Connecticut, reprinted 1978). ${ }^{6}$ 現代の議論としては、例えば、 L.C. Becke, Property Rights - Philosophic Foundations (London, Boston, 1977); A. Ryan, Property and Political Theory (Oxford, New York, 1984); J.O. Grunebaum, Private Ownership (London, New York, 1987); J. Waldron, The Right to Private Property (Oxford, 1988); S.R. Munzer, A Theory of Property (Cambridge,
ものではない。それは大抵の哲学的問題と同様、昔からみられるものであ る。私的所有に対する継続的な関心は、自然法の伝統において研究に取り 組む者にとって重要な意味をもつ問いかけに端を発するものである。それ は、所有権の起源や基盤を探し求めることから構成されるものであった。

自然法論者にとって、所有権の起源の究明はあらゆる確立された個人の 財産保有の正当性を劦か寸可能性がある。そのような革命的な帰結が起こ りえそうであることは、神の存在と聖書の内容を真剣に考慮することから 生じたものであった。ブラックストーンは、その著書『イギリス法釈義』 (Commentaries on the Laws of England) の中で、問題の本質を上手く捉えて いる。彼は次のように指摘する。敄密にいえば、「なぜ羊皮紙に書かれた 文書の文言が土地の支配権を付与寸ることになるのかということについ ての、自然ないし自然法上の根拠は何も存在しない。」๋ キリス卜教におけ る神中心の世界では、この問題は特に深刻である。というのも、神が大地 をその住人に共有のものとして与えたことに疑いはないからである。それ では、いったいどのようにして、この世界における個々の所有者がその所 有物に対して結果的に行使することになる「唯一絶対の支配権」を正当化 寸ることができるのであろうか8。実際のところ、ブラックストーンは「正 当化」という言葉は用いていない。むしろ彼は、私的所有権は広く普及し ており、また一般大衆によって広く受容されているものであるが、それは 説明が必要なものであると考えている。つまり私的所有というものは、法 が合理的科学として機能寸る以上、なお説明を要する現象であるというわ けである。

自然法上の所有理論におけるこうした説明的分析方法の重要性は、グロ ティウスの所有論に見いだすことができる。グロティウスにとって、戦争 の原因の 1 つは、我々に帰属する事物への侵害である ${ }^{9}$ ここうしたことか

1990) がある。議論の概観として、A. Reeve, 'Property' in R.E. Goodin and P. Pettit (eds.) A Companion to Contemporary Political Philosophy (Oxford, 1993), chapter 31 を参照。

${ }^{7}$ Sir William Blackstone, Commentaries on the Laws of England (1765; 1783 ed., reprinted by Garland Publishing, New York, London, 1978), Book II, chapter 1, 2.

${ }^{8}$ Ibid.

${ }^{9}$ H. Grotius, De Hure Belli Ac Pacis Libri Tres (1625; F. W. Kelsey tr., New York, London, 
ら、グロティウスは、ある事物が誰かに帰属するといえるのはどのような 条件の下においてかということを研究するようになり、それはやがて、「所 有権 (proprietorship) の起源を知ることが不可欠である」という彼の考えへ とつながっていくことになる ${ }^{10}$ 。グロティウスが念頭においていた知識と いうのは、歴史的な知識である。「神聖な歴史」、詩人、哲学者らを引き合 いに出しながら、グロティウスは、神が人間に共有のものとして与えた世 界から私的所有権が発展していく態様を描写している ${ }^{11}$ 。この歴史的な研 究はある根本的な原理を確立した。これらはグロティウスにより、具体的 な規範的結論（海洋権や難民の権利など）を生みだすために用いられてい る。少なくともグロティウスにおいて、自然法上の所有理論は説明および 正当化という両方の目的を有する。

時が経つにつれ、一階 (first order) の道徳理論の文脈では、私的所有権 の起源を事実原理から説明することの重要性が薄れていった。一方で、私 的所有権の正当化を行うこと、すなわち財産取得の正当性についての説明 を提示寸ることへの関心は、依然として強く残った。財産権の起源を説明 するという課題は、心理学、社会学、経済学といった経験科学の分野に移 行していったように思われる12。

以上のような所有理論に関するいくつかの基本的区別の簡単なスケッ チをもとにして、本書が知的財産の分析をどのように発展させるのかを今 から説明することにしたい。本書の分析パートは、いくつかの前提の上に 成り立っている。まず、2つの重要な前提が特定される必要がある。第 1 に、分析的所有理論は、権利の形式における所有を概念分析の対象として 捉える。説明の対象は財産権 (right of property; right of ownership と置換可

\section{4), Book II, chapter 2, I.}

${ }^{10}$ Ibid.

${ }^{11}$ Id. at Book II, chapter 2, II, 3.

12 アイディアの専有に関する興味深い心理学的説明として、R.A. Wicklund, “The Appropriation of Ideas' in P.B. Paulus (ed.), Psychology of Group Influence (2nd ed., Hillsdale, NJ; Hove, London, 1989) を参照。ゲーム理論を用いながら財産権の起源に ついても一部取り披う、財産権に関する経済学的説明として、D. Friedman, “A Positive Account of Property Rights’, 11 Social Philosophy and Policy, 1 (1994) を参照。
能な用語として用いられる場合もある）である。ホーフェルドによれば、 我々は権利をそれに基づいて演繹を始める基底的なターム（base terms）と して扱うべきではなく、一連のより基本的なカテゴリーに分解しうる一般 的なターム (generic term) として扱うべきである。権利は、財産権を含め て、論理アーキテクチャー (logical architecture) を有している。この論理ア

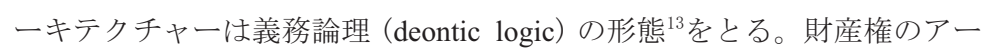
キテクチャーを特定するうえでは、複数の義務論理の選択肢が存在する ${ }^{14}$ 。 所有権理論の枠内では、通常、ホーフェルドの体系がそうした目的のため に選ばれる ${ }^{15}$ 。ここではその慣習に従うことにする。

所有とは物（a thing）であるという考えは、今日では古くさい誤った見方 であると考えられている。少なくともそうした考えは有益ではないとされ る。所有とは、一対一の私人間の権利関係（つまり single-place の関係）、 あるいは一対多の私人間の権利関係 (つまり many-place の関係) であると 考えられている ${ }^{16}$ 。所有は人々が必要ないし希望する、そして時には個人 であれ集団であれその生存が依存することもある、そのような対象の支配 をめぐる争いである。オノレ (Honore) が我々に気づかせてくれるように、 「所有者と所有物とを直接つなぐイディオムは、決して無意味なものでは ない。すなわち、他者を排除する権利が存在するところには、実際、（法 的には）権利の保有者と当該物との間に非常に特別な関係が存在している のである。」 ${ }^{17}$

ここではこれ以上の深入りは避け、次に進もう。我々の第 2 の前提は、 財産権は私人間の関係にくわえて、人と対象との関係をも伴うというもの である。知的財産法の場合、問題の対象は abstract objects である。しかも、

${ }^{13}$ 寸なわち、道徳的要請と道徳的概念の領域における、フォーマルな議論と言語に 関する研究とその展開のことである。

14 サーベイおよび議論として、L. Lindahl, Position and Change (Dordrecht, Boston, 1977) を参照。

${ }_{15}$ 最近の例として、S.R. Munzer, A Theory of Property (Cambridge, 1990) を参照。

${ }^{16}$ 後者の見方が論理的に誤っている理由については、 L. Lindahl, Position and Change (Dordrecht, Boston, 1977), 37 を参照。

${ }_{17}$ A.M. Honoré, 'Ownership' in A.G. Guest (ed.), Oxford Essays in Jurisprudence (Oxford, 1961), 106, 134 . 
あいにくなことに、abstract objects は存在しない、あるいは少なくとも我々 はそのように主張する。知的財産法における abstract objects は勝手のよい 法的フィクションの形をとる。この点に関する議論は、第 2 章および第 7 章で展開される。この法的フィクションの心理的作用は、遂行的発話論 (theory of performative utterances）の観点に基づいた説明をなすことが最も 有益であると思われるが、しかし、それは我々がここで追究すべき問題で はない ${ }^{18}$ 。

知的財産法に関する多くのテキストは、知的財産の定義に関する記述か ら始まる ${ }^{19}$ 。定義というものは、外延的にも内包的にもなすことが可能て ある。知的財産の外延的定義 (extensional definitions) は、知的財産のいく つかの伝統的な中心分野を掲げるだろう。例えば、著作権、特許、商標、 意匠、不正競争防止法、トレード・シークレットの保護などである。（本 章の最終節には、これらの分野に関する簡単な説明のノートがある。）時 の経過とともに、新たな対象分野がこのリストに現れてきた。集積回路配 置の保護や植物新品種の保護などはその例である ${ }^{20}$ 。一方、知的財産の内 包的定義（intentional definitions）について体系的に述べることはより難し い21。ここでは、知的財産権とは、多方面の分野の人的活動における

18 北欧リアリズム法学の伝統に属する学者は、遂行的発話論を利用して法律用語の 本質を説明した。K. Olivecrona, 'Legal Language and Reality' in R.A. Newman (ed), Essays in Jurisprudence in Honor of Roscoe Pound (Indianapolis, New York, 1962), 151; K. Olivecrona, Law as Fact (2nd ed., London, 1971) を参照。

19 従来、工業所有権や知的財産権と呼ぶことが慣例であった。「業」(industrial) という用語は、特許や意匠のような、技術ベースの対象分野をカバーするために用 いられた。「知的財産」(intellectual property) という用語は、著作権やその文化的保 護対象に言及寸るために用いられた。今では多くの人々は、工業所有権および知的 財産のあらゆる分野をカバーするために、「知的財産」という用語を一般的に用い ている。本書でもこうした現代の慣例に従うことにする。

20 両者はいずれも国際条約の対象である。1962年12月 2 日に修正された植物の新品 種の保護に関する国際条約、および集積回路に係る知的所有権に関する条約（ワシ ントン、1989）を参照。

21 包括的な形で表現された、かなり広範な知的財産権の定義の一例は、1967年 7 月 14日にストックホルムで署名された世界知的所有権機関を設立する条約（WIPO 設 abstract objects の所有および利用を規律する、ルールに支配された特権 (rule-governed privileges) であると定義することにしたい。この定義はより 一層概念的な結論である。それは、後続の章で提示される、知的財産に関 する特定の理論的視点に基礎をおくものである。

本書の議論が導きだす規範的結論は、知的財産権とは自由を侵害する特 別な特権 (liberty-intruding privileges of a special kind) であるというもので ある。知的財産権は派閥主義を促し、危険な私的権力のレベルを増進させ るという議論が展開される。分配的正義の観点からは、知的財産権の保護 範囲は制限されるべきである。そうした権利について考える方法は、自然 主義的経験主義のレンズを通してである。これらの主張に関する議論は第 6〜9章で展開される。本書では、私的所有の新たな正当化根拠を探求する ような試みは行わない。エプスタイン (Epstein) が指摘するように、「私的 所有の望ましさは、これまで学問分野を超えて延々と議論されてきた。」 私的所有を支持する理路整然とした哲学的提言であふれている ${ }^{22}$ 。それら は多すぎるぐらいかもしれないとベッカー（Becker）は最近の論文におい て示唆している ${ }^{23}$ そしてベッカーがそれとなく历めかしているように、 我々は利用可能な私的所有の道徳的正当化論の数を増や寸ことよりも、さ まざまな社会生活分野において私的所有がもたらす経験的に決定しうる

立条約) の第 2 条 (viii)においてみられる。同条項は、「知的財産」とは以下に関連 する権利を含むものをいう、と規定している。

文芸、美術及び学術の著作物

実演家の実演、レコード及び放送

人芸の活動の寸べての分野における発明

科学的発展

意匠

商標、サービス・マーク及び商号その他の商業上の表示

不正競争に対する保謢

に関する権利並びに産業、学術、文芸又は美術の分野における知的活動から生ず る他のすべての権利。」

22 R.A. Epstein, 'On the Optimal Mix of Private and Common Property', 11 Social Philosophy and Policy, 17(1994)

${ }^{23}$ L.C. Becker, 'Too Much Property', 21 Philosophy and Public Affairs 196 (1992). 
帰結に、より多くの関心を払うべきであろう。私的所有権を支持する強力 な理由は確かに存在するが、我々はそうした理由づけを条件つきの帰結主 義的な思考方法で行うべきである。もし私的所有権の一種である知的財産 権が、消極的自由を劦か寸ような組織化のパターンや慣習を促進するとい うことが判明すれば、これらの権利の保護範囲を厳格に制限したり、その 中のいくつかの権利を完全に廃止したりすることを支持する根拠が存在 することになる。本書は、知的財産権がこうした脅威を与えるものである と考える論拠を提示するものである。しかしながら、結局のところ、これ は私的所有のア・プリオリな正当化に基づいて判断することができる問題 ではない。我々が念頭におくアプローチは、社会生活や民主主義文化にお いて所有が果たす役割についての、哲学的に擁護可能な視点によって導か れる。この点に関する我々の提言は、ヒューマニズムの原則に賛同する道 具主義（instrumentalism）の形でもたらされる。

\section{経済学理論}

知的財産権は市場と緊密に関係している。知的財産権は、情報市場を形 成するうえで重要な役割を果たしている。経済学理論は、知的財産権の哲 学的議論において無視することができないほど非常に重要な資料である。 同理論はまた、1つの研究でカバーすることができないほど非常に大規模 な資料でもある。経済学はアプローチに富んだ学問領域である。その範囲 を狭いなどと評することはとてもできない。例えば、ダグラス・ノース （Douglass North）の研究に代表される新たな経済史というものは、新古典 派経済学のアプローチに対する情け容赦ない批判である ${ }^{24}$ 。情報経済学は、 新古典派経済学のパラダイムにとって危険な補完機能を果たすようにみ える ${ }^{25}$ 。制度派経済学は、power というものは単なる市場支配力よりも複

24 ノースの著作としては、 D.C. North and R.P. Thomas, The Rise of the Western World: A New Economic History (Cambridge, 1973); D.C. North, Structure and Change in Economic History (New York,1981); D.C. North, Institutions, Institutional Change and Economic Performance (Cambridge, New York, 1990) がある。

25 情報経済学の重要な貢献に関する文献として、D.M. Lamberton (ed.), The Eco-
雑な概念であるということを認める ${ }^{26}$ 。公共選択論は、少なくともその擁 護者からみれば、政治理論に足を踏み入れて実りある成果を挙げてきたこ とは明らかである ${ }^{27}$ 。シカゴ学派は、法の性質についての重要かつ刺激的 な主張を生みだし続けている 28 。一連の重要な実証研究も存在し、図らず もその大部分は特許制度に関するものである ${ }^{29}$ 。

したがって、所有理論を展開する経済学外の論者にとっては、利用しう る研究の数が多寸ぎるといえる。本書は経済学に関する書物ではなく知的 財産の哲学に関する書物であるので、選択をなすことが必要である。

多くの知的財産立法が有する明らかな経済学的性質を考えると、検討に 值する 1 つの可能性は、何らかの経済学理論が各種の知的財産権の制定を 正当化する根拠を提供するかもしれないというものである。もちろん、こ れらの権利は法律の詳細や性質において相互に大きな相違がある。特許に よる独占は同一発明を独自に発見した者に対しても行使可能な禁止権を

nomics of Information (Harmondsworth, UK, 1971); D.M. Lamberton (ed), The Economics of Communication and Information (Cheltenham, UK, 1996) を参照。

${ }^{26}$ この種の研究にインスピレーションを与えた古典的文献は、J.R. Commons, Institutional Economics (New York, 1934) である。

${ }^{27}$ I. McLean, Public Choice: An Introduction (Oxford,1991); D.A. Farber and P.P. Frickey, Law and Public Choice: A Critical Introduction (Chicago, 1991) を参照。

${ }^{28}$ R.A. Posner, Economic Analysis of Law (4th ed., Boston, 1992) が、こうしたアプロー チの象徴である。

291 つの古典的な研究は、F. Machlup, An Economic Review of the Patent System (Study No. 15 of the Subcommittee on Patents, Trademarks, and Copyrights of the Committee on the Judiciary, U.S. Senate, 85th Congress, Washington, D.C., 1958) である。このほかにも 重要な研究として、例えば、E.T. Penrose, The Economics of the International Patent System (Baltimore, 1951); J. Schmookler, Patents, Invention, and Economic Change (Z. Griliches and L. Hurwicz eds., Cambridge, Mass., 1972); C.T. Taylor and Z.A. Silbertson, The Economic Impact of the Patent System (Cambridge, 1973) がある。オーストラリアの 立場からみた特許の経済学の議論として、T. Mandeville, D. Lamberton and J. Bishop, 'The Use of Patent Information: Economics of Disclosure' in The Economic Implications of Patents in Australia (Canberra, 1981), 271 を参照。特許制度が発展途上国にもたらす影 響に関する議論として、A.S. Oddi, 'The International Patent System and Third World Development: Reality or Myth?’, Duke Law Journal, 831 (1987) を参照。 
特許権者に付与するのに対し、著作権は複製行為を禁止する権利を付与し ているが、同一著作物を独自に創作する行為についてはこれを禁止してい ない。これらの重要な相違にもかかわらず、知的財産権は基本的な性質を 共有する。すなわち、知的財産権は abstract objects に対する権利であると いうことである。このような類似性により、経済学者および哲学者は同一 の質問をなすことが可能となる。すなわち、abstract objectsに財産権を創 設することを正当化する根拠は何かという問いである。

この問いに対して経済学者は、人間性についての基本的な直観、あるい は形而上学といってもよいが、そうしたものから分析を始める。人はイン センティヴや報酬に対してポジティブに反応寸る。もし abstract objects の 創造において個人的利益を期待するのであれば、それらの abstract objects は何らかの方法で、少なくとも一時的に囲い込まれなければならない。こ のことは、経済学者に対して、財産権が abstract objects の創造に向けた個 人のリソース投入を十分かつ確実なものにする最良の方法であるかもし れない可能性について検討するよう、働きかけるものである。ここにおい て我々は、知的財産権の創出を支持する根拠を提供する経済学的議論を概 略ながら手にするのである。我々はそうした議論を第 6 章において検証す る。

経済学者は、他の社会理論学者や政治理論学者と同様、power に関心が ある。経済学者はしばしば市場支配力、つまりごく簡単にいえば、限界費 用を上回る価格をつけることができる powerに最も関心を寄せている。制 度派経済学においては、power は単に価格機構を通じてもたらされるもの ではなく、市場を形成し創出するものとして、より広く捉えられているよ うにみえる。第 7 章において我々は、知的財産と power の関係に関する分 析を発展させるため、古典的制度学派の論者の一人であるべブレンの業績 を利用する。

経済学者はまた、論理関係、形式的特性、そして演繹的真実に関心を寄 せる。我々が先ほど概略を述べた知的財産に関する経済学的正当化の議論 は、推論的ないし分析的議論の一例である。さらに推し進めて、知的財産 権がいかにして厚生全体の利益を促進するのかということの説明を行う、
知的財産保護に関するフォーマルなモデルを構築することもできる ${ }^{30}$ 。フ オーマルなモデルは興味深い分析的真実を伝達することができるけれど も、この世界についての真相を確認するためには、統計的定量化および／ または実証的研究が必要となる。経済学には、そのフォーマルなモデル構 築に基づく規範的なアウトプットが生き長らえる運命にあるのか、それと も息絶える運命にあるのかを決する、妥協を許さない厳格な実証的側面が ある。知的財産権の保有を支持するア・プリオリな経済学的議論を展開す ることは可能である。しかし、それで事が終わるわけではない。知的財産 権に関する経済学的判断は、最終的には費用便益計算の結果に基礎をおく ものでなければならない。シンプルな例で考えてみよう。意匠法の保護が 自動車のスペア・パーツには及ばないというケースを想定してみよう31。 これは多くの法域に当てはまる状況である。自動車メーカーの団体に雇わ れた経済学者が、意匠法の保護がスペア・パーツにまで拡大されるとすれ ば、デザイン・イノヴェーションにとってネットの利益を期待しうること を示すモデルを構築したとしよう。ここで同じ経済学者がそのモデルに関 寸るいくつかの前提について検証を行う。そして彼はある主要な前提が誤 りであることを発見する。具体的には、メーカーがデザインに継続的に投 資を行う動機となっているものは、一定のデザイン保護の水準というより も、むしろ市場の圧力であるということを発見するのである。さらに、現 実のデザイン投資水準が表しているものは、実際には自動車メーカーの費 用のうちのごく一部、具体的には 1 パーセント以下のものにすぎない。こ のことが意味するのは、デザイン活動の損失という点に関してフリーライ ダーがもたらす費用の影響は非常に小さいものであるということである。 こうして、デザイン保護を拡大することから得られるはずの効率性の向上 は実際には期待できないということが明らかとなる32。自動車メーカーは

30 例えば、W.M. Landes and R.A. Posner, 'An Economic Analysis of Copyright Law', 18 Journal of Legal Studies, 325 (1989); W.M. Landes and R.A. Posner, 'Trademark Law: An Economic Perspective', 30 Journal of Law and Economics, 265 (1987) を参照。

31 サーベイとして、Australian Law Reform Commission, Designs (DP 58, Australia, 1994), chapter 14 を参照。

${ }^{32}$ Industry Commission, Report on Vehicle and Recreational Marine Craft Repair and 
当てがはずれ、落胆し、法律家に「適切な仕事」をさせなければならない などとぶつぶつと不平をいうほかにすることがなくなるだろう。

知的財産の分野において、こうした費用便益アプローチの例はほかにも 数多くみられる。最適な保護期間をめぐる議論はその 1 つである ${ }^{33}$ 。おそ らく、知的財産分野において経済学ができる最も大きな貢献は、知的財産 に関するさまざまな取決めの帰結を経験的に跡づけることである。本書の 最終章で我々が提示する道具主義という考え方は、そのような経済学の貢 献に大いに頼るものである。もし費用便益アプローチをもたなければ、知 的財産権は不透明な制度にとどまるだろう。とりわけ、国家、議会、そし て裁判官が abstract objects の境界を変更し、知的コモンズにおける新たな 囲い込みの境界線を設定する場合に、誰が真の勝者であり敗者であるのか ということが分からなくなってしまうだろう。

\section{本書各章の概観}

我々は、知的財産法における abstract objects の歴史についてごく簡単に 論じることから始める。その目的は、英国法がどのようにして abstract object のカテゴリー、あるいは法律家の用語でいうところの incorporeal rights を作りだすようになったのかを示すことである。こうした概念を創 出した起源はローマ法である。第 2 章はまた、コモン・ローの判決におい て見いだされる知的財産権の正当化根拠について扱う。コモン・ローは著 作権および特許権の正当化の問題に取り組まなければならなかった。とい うのも、著作権や特許権は、特に制定法以前の形態においてはコモン・ロ 一の基本原則、つまり営業を行う国民の権利、より正確には取引市場に参 入する権利に反するものであったからである。この問題に対処する概念装 置は自然法の伝統によってもたらされた。そしてこうした伝統の枠内にお いて、対照的な正当化のアプローチが生みだされたのである。

そうした伝統のメンバーの一人が、ジョン・ロック（John Locke）である。

Insurance Industries (Australia,1994), 123 を参照

${ }^{33}$ この点については、L. Kaplow, 'The Patent-Antitrust Intersection: A Reappraisal', 97 Harvard Law Review, 1815, 1823-1829 (1984) の議論を参照。
第 3 章の前半は、所有に関するロックの著作についての大きく異なった 2 つの解釈の説明にあてられる。これらの解釈は、いわゆるロック労働所有 理論がそのもつともらしさの基盤を労働よりも共同体の概念 (a concept of community）においているということを明らかにするために用いられる。 労働というものは、知的財産権の強力な正当化理論を構築するにはあまり に不確定な基盤であるというのが我々の主張である。知的財産権にとって ロックが有する実質的な関連性というのは、ロックや他の自然法思想家が 見いだした、積極的および消極的共有概念と所有との連関、つまり共有物 が万人によって所有されている共同体と共有物が万人の所有に開かれて いる共同体との連関にある。第 3 章の後半は、共同体、知的コモンズ、そ して知的財産権の相互関係について探求する。

ロックと異なり、ヘーゲルは単に所有の起源を理解することのみならず、 社会システムの文脈におけるその発展結果にも関心がある。へーゲルにと って所有は、まず第 1 に個人の生存にとって基盤となるメカニズムである。 しかし所有はまた、さまざまな形で共同体を決裂させる可能性を有するも のでもある。知的財産は特にこの種の危険をもたらす。

マルクスは、ヘーゲル以上に、所有形態についての説明的な視点を提供 する。第 5 章は、知的財産についての理解を深めるうえで、マルクスの階 級理論は有益ではないが、個人資本家の身に迫る競争圧力についてのマル クスの分析は有益であると思われる、ということを論じる。マルクスは生 産の物質性に固執したために、資本主義の商品蓄積プロセスにとっての abstract object の重要性を看過することになった。しかし、資本主義が存続 するためには創造的労働 (creative labor) が重要であるというマルクスの 認識は、個々の競争主体として資本家を捉える彼の理解と相まって、知的 財産権の任務を明確に特定することを可能にするものである、というのが 我々の主張である。

第 6 章は、経済学者に対する深刻な批判を提示する。それは、経済学者 は個人の利已的な行動を一少なくとも知的財産権の場合には一十分真剣 に考慮していないというものである。その結果、知的財産権がもたらす現 実の費用は、最初に想定されるものよりもずっと大きなものとなる可能性 が高い。これらの費用の要因は、市場における機会主義的なアクターが採 用する抑止戦略にある。知的財産権はこうした戦略を生みだす源泉なので 
ある。知的財産権は他の所有形態よりも派閥の問題を招きやすい。

第 6 章において暗示されているのは、知的財産と power の関係である。 この関係の本質は、第 7 章において分析がなされる。我々の主張は、所有 とは支配権メカニズム (sovereignty mechanism) であり、それは知的財産の 場合には支配権効果（sovereignty effects）をもつというものである。この第 7 章では、abstract objectの本質について第 2 章よりも詳しい分析を行う。 abstract objects は一種の重要な資本である。無体物はさらに「人的依存」 関係をも作りだす。そうすることで、 abstract objects はある種の強制的な 請求を実現可能なものにしているのである。

abstract objects は基本財 (primary good)の1つである。我々はそれらの 分配について規範的に考えなければならない。第 8 章は、ロールズの正義 論のもとで知的財産権の運用はどのようになるのかということを尋ねる。 最終章は、知的財産法の発展を支配するようになった信条の 1 つが財産権 優越主義（proprietarianism）であることを論じる。そして同章では、財産権 優越主義の代替案として道具主義を提案する。道具主義は知的財産権を自 由を侵害する特別な特権であるとみなす。財産権優越主義の影響のもとで は、これらの特権は消極的自由に対して大きな劦威をもたらすようになる。 本書が提唱する道具主義は、ヒューマニズムの原則によって導かれる自然 主義的経験主義の形をとる。

\section{知的財産権の対象分野に関するノート}

知的財産権の伝統的な主要分野に馴染みのない読者のために、ここであ えて過度に単純化した解説を展開しておこう。これらの分野は通常、制定 法によって規律される。これらの制定法の内容は各国の国家政策の問題で あるが、知的財産権保護の最低水準 (minimum standards) を規定する国際 条約は増加している。一般に、知的財産法は関連する対象に私有財産権を 創設する。このことは、例えば、特許権の譲渡やライセンスが可能である ということを意味する。特許権のような一部の権利は保護期間が限定され ている。これに対し、他の権利、例えば商標権には保護期間の限定がない。 著作権は、文学作品や芸術作品のような伝統的文化的著作物に対する著作 者の権利を取り扱うものである。著作者が取得する権利の例としては、複

16 知的財産法政策学研究 Vol. 34(2011)
製権や公の実演権などがある。著作権の保護は、従来の権利の拡張（例え ば、文学作品としてコンピュータ・ソフトウェアを保護すること）を通じ て次第に拡大され、また新たな対象分野（例えば、サウンド・レコーディ ングや映画）にも拡大されてきた。

特許法は発明を保護している。その保護は、発明性や新規性をはじめと するさまざまな要件の充足を条件とする。意匠法は工業製品の外観につい て扱うものである。(トイレの便器の外観は意匠登録の対象となりうる。 彫像の形状は著作権保護の問題となる。）商標法は事業者が自他商品・役 務を識別するために用いる標識（sign）を保護するものである。「標識」は 今では広範な意味を有しており、それには香りや音も含まれる。

不正競争防止法は漠然とした領域である。工業所有権の保護に関するパ リ条約 (1883年) の改正後の 10 条の 2 は、工業上または商業上の公正な慣 習に反するす心゙ての競争行為は不正競争行為を構成する、と規定している。 知的財産権の分野の中では一番、不正競争に関連する法律が各国で極めて 多様な方向へと発展を遂げている。

トレード・シークレット法は、非開示選択がなされた商業的に有用な技 術情報に対する保護を提供するものである。同一の abstract object は複数 の知的財産法分野のもとで保護を受ける可能性がある。アルゴリズムは、 特許法、著作権法、トレード・シークレット法のもとで保護を受ける可能 性を秘めている。標識は、商標であると同時に芸術作品であるかもしれな い。ある対象に対する保護の選択は、ビジネス戦略の問題である。各法制 度は異なったメリットとデメリットを有している。リバース・エンジニア リングが容易な製品（例えば機械）については、トレード・シークレット の保護よりも特許保護を選択するほうが望ましい。なぜなら、トレード・ シークレット法は、独立の開発者に対する権利行使を認めていないからで ある。特許保護に伴う 1 つの問題は、有限の保護期間である。もしリバー ス・エンジニアリングが容易にはできない製品であれば（コカ・コーラの レシピがこのカテゴリーに入るといわれている)、トレード・シークレッ トの保護に頼るほうが望ましい。なぜなら、一定の条件を充足すれば、そ の保護は無限に続くからである。 


\section{第 2 章 知的財産権の正当化：起源に遡って}

\section{なぜ歴史なのか？}

歴史は哲学にとって重要である。もしそうでなければ、哲学的な分析作 業はより単純なものになるであろうから、大いに助かるのだけれども。な ぜ知的財産権の分析に何らかの歴史が導入されるべきかということに関 しては、少なくとも 3 つの理由がある。第 1 に、分析作業を行ううえで選 択されるかもしれない一部の哲学的枠組みは、必然的に歴史を利用寸るも のだからである。史的唯物論というマルクスの理論を(単純かつ機械的に) 適用しながら、知的財産権は資本主義社会の発展における工業化（おそら くは脱工業化）段階に対応する上部構造現象であるという主張をな寸者が いるかもしれない1。そのような説明は、歴史的証拠によってのみ妥当な ものとなりえるだろう。

第 2 に、歴史は知的財産権の経済分析や帰結主義的分析にとっても重要 だからである。これらのタイプのアプローチは、福祉、経済成長、文化保 護、クリエイティビティに対する報奨等といった一定の規定された目標の 実現にとって有益であることを理由に、知的財産権の創設を正当化するで あろう。このようなアプローチにとって、歴史上の実際のデータは、ア・ プリオリな理論よりも知的財産権の効果を理解するうえで好ましい資料 となるであろう。第 3 に、歴史的な視点は、クェンティン・スキナー (Quentin Skinner) が政治哲学との関係で説明しているような理由で、知的 財産権の哲学的位相に関寸る我々の理解を深めてくれるものだからであ

1 これは、マルクス主義者が知的財産に対して必然的にこのような方法でアプロー チ寸るということをいっているわけではない。マルクスの感化を受けた伝統の中に は、より複雑に、かつよりニュアンスをともなった法の分析を行う議論も存在する。 例えば、 K. Renner, The Institutions of Private Law (O. Kahn-Freunded., A. Schwarzchild tr., London, 1949); E.B. Pashukanis, Law and Marxism: A General Theory (C. Arthur ed., B. Einhorn tr., London, 1978) を参照。著作権法を用いてその法理論の一部の要素を構築 するマルクス主義的な論法として、B. Edelman, Ownership of the Image (E. Kingdom tr., London, Boston, Henley, 1979) を参照。
る2。スキナーの方法論的主張とは、政治哲学の基本的諸概念に関する現 在の意味は、これら諸概念の歴史的時系列をそれぞれたどり、それらを使 用寸る者の社会的コンテクストとそれらの使用を取り巻く前提の双方を 明らかにする、言語学的分析を通してのみ理解できるというものである。 スキナーが念頭においている、哲学的、歴史的、言語学的分析からなる複 合的なゲーム分析は、知的財産権の文脈において実施されたことはない。 そうした分析は本書でも行わない。これは明らかに専門家の仕事である。 しかし、スキナーの一般的な方法論的主張は、知的財産権の哲学がなぜ歴 史に背を向けてはならないのかということに関する別の理由を提供する。 知的財産権の哲学が少なくとも何らかの歴史を必要とするということ の論証をし終えると、すぐにその次の作業として、我々は現在の目的に鑑 みて史料の利用範囲を限定しなければならない。明らかに、著作権や特許 制度のような、ある 1 つの知的財産制度に関する国家の歴史というものは、 それだけで独立した研究対象となりうるだろう。かりに歴史的研究の範囲 をヨーロッパ諸国における制定法や裁判官の創造した法 (judge-made law) に制限したとしても、何世紀にも及ぶ膨大な史料が存在する。「知的財産」 (intellectual property) という語は、互いに独立して、異なる時代に異なる 場所で誕生した法制度群を指し示す、20世紀における一般名称である3。 例えば、イングランドは、1709年にアン法典 (Act of Anne) と呼ばれる著作 権法を世界で初めて制定した国であるとしばしば認められている。また、 ベネチア人は世界で最初の特許法を制定したと考えられている4。しかし、 どのような場合でも、知的財産法の歴史は制定法から始まっているわけで はない。イングランドにおける著作権や特許権は、もともと国王大権

2 主に精神史において生じているようにみえるこうした議論の雾囲気として、J Tully (ed.), Meaning and Context: Quentin Skinner and his Critics (Cambridge, 1988) を参 照。このほか、D. LaCapra and S. Kaplan (eds.), Modern European Intellectual History: Reappraisals and New Perspectives (Ithaca, N.Y., 1982) も参照。

3 工業所有権と著作権の双方を指し示寸用語として「知的財産」という語が初めて 使用されたのは、1950年代に入ってからであるように思われる。A. Bogsch, Brief History of the First 25 Years of the World Intellectual Property Organization (Geneva, 1992), 8 を参照。

S. Ricketson, The Law of Intellectual Property (Sydney, 1984), 860-861. 
(prerogative)、特権 (privilege)、および独占 (monopoly) という複雑な制度 から生まれたものである。同様に、ロシアを含めた多くのヨーロッパ諸国 では、工芸技術を規制する国王令 (royal decrees) や特権という複雑な制度 が存在した ${ }^{5}$ 。

本章では、 2 つ作業が史料の選別を規定している。第 1 の作業は、知 的財産権の法的分類に関係するものである。1つの可能性は、英国財産法 における知的財産権の分類方法から、我々は知的財産権一の何らかの哲学 的洞察を得られるかもしれないということである。英国財産法の内部にみ られる独自の分類構造は、我々が知的財産権の性質を理解するのに有益で あるかもしれない。このことは、そのような法的性質それ自体が一定の既 存の哲学的思想や作用に基礎をおくものであるとすれば、とりわけ当ては まる。こうした可能性は軽視されるべきではない。後でみるように、知的 財産権を incorporeal rights として法的に分類することは、直ちに abstract objects という哲学的概念へと結びつくものである。この哲学的概念と財産 概念との融合は、第 7 章で述べるように、現代の経済システムにおける権 力の基礎が abstract objects の支配に横たわっているという議論にとって重 要なものとなる。

法的史料についての第 2 の用途は、初期の英国著作権法や特許法にみら れる正当化根拠を検証するというものである。当然ながら、哲学者はこれ らの正当化根拠に拘束されるものではない。こうした史料は、知的財産権 に関する初期の正当化アプローチが極めて道具的なものであったという 主張を裏づけるために用いられる。本書の最終章では、道具的な態度が知 的財産権における理論発展を特徵づけるべきであるという規範的議論を 展開するために、こうした史料がより頻繁に利用されることになる。

作業を開始する前に、知的財産権制度の批判的評価において歴史が果た しうる役割についての、より一般的な考察を俯瞰しておこう。歴史という のは一種の特殊な物語であるが、知的財産権はより多くの歴史的批判的物 語を必要と寸る分野である。そうした物語の 1 つの目的は、知的財産権の

${ }^{5}$ F. Machlup and E. Penrose, 'The Patent Controversy in the Nineteenth Century', 10 The Journal of Economic History, 1, 2 (1950) を参照。ロシアに関しては、J. Vojacek, A Survey of the Principal National Patent Systems (London, 1936) を参照。
オーソドックスな正当化根拠の評価を支援する点にあるだろう。現に、本 書で検討されている歴史は、さまざまな社会がその制度的な組織および規 範の観点から人類のクリエイティビティ一科学的および非科学的なもの の両方を含む一を奨励し利用してきた過程に関する、一連の歴史である。 例を挙げて説明すると、知的財産権の創設を正当化するために用いられる 基本的な議論の形は、知的財産権は特定の権利の適用対象となる活動に従 事するインセンティヴを人々に与えるというものである。この議論によれ ば、特許権は発明を奨励するためのものである。発明やイノヴェーション の促進を望む社会にとって、財産権というものが唯一の手段であるのかど うかを歴史は我々に教えてくれるだろう。中華帝国（Imperial China）は、 科学とイノヴェーションにおいて目覚ましい成果を挙げた社会の一例で あるが 6 、知的財産権やそれと同等の慣習に頼っていなかった 7 。知的財産 権、科学、経済発展という三者の関連性は、必然的かつ普遍的 (necessary and universal) なものというよりは、偶発的かつ地域的 (contingent and local）なものであるということを歴史は我々に教えてくれるであろう。

そうした歴史的批判的研究が寄与しうる他の目的も存在する。そうした 研究は、知的財産権に関寸る我々の分析が陥りがちなヨーロッパ中心志向 の見方を緩和してくれるだろう。そこから得られる証拠は、知的財産とは さまざまな社会によりさまざまな形で設定されてきた多様な概念である ということを示唆している。ローウィ (Lowie) の人類学的研究は、 incorporeal property（無体財産）という概念、とりわけ特許および著作権と

${ }^{6}$ J. Needham, The Grand Titration (London, 1969)を参照。このほか、J. Needham, Science and Civilization in China (Cambridge at the University Press, 1954 v.1-) シリーズ の各巻も参照。

7 このことは次のような問題を提起する。すなわち、中華帝国はいかにして、知的 財産権が存在しない状況においてこのような輝かしい実績を打ち立てることがて きたのか、といらことである。これは科学技術史の研究者にとっての課題である。 しかし、知的財産権が何ら役割を果たさなかったということには疑いがない。中華 帝国には知的財産権に相当する法的ないし慣習的な制度は存在しなかったからで ある。W.P. Alford, 'Don't Stop Thinking About ... Yesterday: Why There was No Indigenous Counterpart to Intellectual Property Law in Imperial China', 7 Journal of Chinese Law, 3 (1993) を参照。 
いう概念が、アンダマン諸島の住民（the Andaman Islanders）、カイ人 (the Kai)、コリヤーク族（the Koryak）、およびプレーンズ・インディアン (the Plains Indians）の間で高度に発展していたことを明らかにしている8。これ らの社会は、西洋のアプローチとは対照的に、そうした権利の譲渡可能性 を制限することに大きな関心を払っていた。

知的財産権の歴史はまた、知的財産権の理解を経済学のストーリー・テ ラーに過度に依存することから守ってくれるだろう。伝統的な経済アナリ ストが財産一般に関する理解の手がかりとして残寸指標は、さまざまな価 值と財産との連関について明示的に取り扱うものではないし、権力 (power)、統治 (domination)、搾取 (exploitation)、統制（control）といった テーマ、つまり歴史家にとっては非常に馴染みのあるテーマを明示的に取 り扱うものでもない。財産のルールは、ほかの大半のルール以上に、一定 の社会の基本的な道徳に根ざすものである。例えば、西洋の著作権法は、 個人のクリエイティビティや個人の権利の重要性を奨励する芸術観を反 映しているが、それは東洋には実質的に類似するものがない考え方である9 西洋型の知的財産制度が非西洋諸国に移植されるとき、経済学のストーリ ー・テラーの指標は、同制度の導入を行う人々によって批判的に読み取ら れる必要がある ${ }^{10}$ 。外国の法制度モデルの導入に関する決定は、いわばイ ンフォームド・コンセントとともに行われなければならない。歴史的批判 的物語を記述することは、知的財産権の法的伝統を受容する人々がそのこ とがもたらす帰結全体について理解を深めることに寄与しうるのである。

\section{知的財産権の分類：ローマは物語る}

知的財産権を学ぶたいていの学生は、corporeal property（おおよそ tan-

${ }^{8}$ R.H. Lowie, Primitive Society (New York, 1920), 235-243.

${ }^{9}$ A. Hauser, The Social History of Art (S. Godman tr., London, 1951), volume 1, 65-66 を 参照。

10 こうしたグローバリゼーションの最も明白な例は、1994年 4 月15日にマラケシュ で宣言されたウルグアイ・ラウンド多角的貿易交渉の結果を収録する最終文書の付 属書 $1 \mathrm{C}$ に含まれる、知的所有権の貿易関連の側面に関する協定である。 gible property (有形財産) に相当) と incorporeal property（おおよそ intan一 gible property (無形財産) に相当)の区別について教わり、そして知的財産 権は incorporeal rights の一例であると教わる。このことが直ちに引き起こ 寸分析的な難問は、 corporeal rights（有体の権利）の可能性そのものである なぜなら、あらゆる権利は incorporeal rights であると考えるのが最も適切 であるように思われるからである（権利を鋤で耕すのは困難である）。こ の難問に対する司法の解答は、これは大雑把ではあるが一般的な言い方で あり、先の区別は権利の性質に着目したものではなく、権利が言及してい る対象の性質に着目したものであるという答えである11。あらゆる権利は incorporeal であるが、財産の一部はそうではないというわけである。

corporeal things と incorporeal things の区別は、古代ローマ私法において みられる ${ }^{12}$ 。我々は『ガイウス法学提要』(Institutes of Gaius) から知ってい るように、古代ローマ法は、あらゆる法を、人の法 (the law of persons)、 物の法 (the law of things)、訴訟の法 (the law of actions) という 3 つに分類 していた。corporeal と incorporeal の区別は、物の法において生じる。この ことはガイウスによって次のように記述されている13。

11 これは、ウィンディヤー判事 (Windeyer J) が Pacific Film Laboratories Pty. Ltd. v Federal Commissioner of Taxation (1970) 121 C.L.R. 154, at 168 において当該問題に対 処した方法である。

12「古典時代」(classical period) という表現は、何人かの著者によってプリンキパト ウスーアウグストゥス治世（27 B.C.）からディオクレティアヌス治世 (284 A.D.) の初めまでの期間一を指寸表現として用いられている。F. Schulz, Classical Roman Law (Oxford at the Clarendon Press, 1951), 1 を参照。

${ }^{13}$ The Institutes of Gaius (F. De Zulueta (ed. and tr.), Oxford at the Clarendon Press, 1946), Book II, 12-14. この区別は、Justinian's Institutes (translated with an Introduction by Peter Birks and Grant McLeod, Ithaca, New York,1987), 2.2 においても同様に記述されてい る。すなわち、

corporeal な物もあれば、incorporeal な物もある。1．corporeal things は実際に触 れることができるものである。一例えば、土地、奴隷、衣服、金、銀、および その他多数の物である。2. incorporeal things は触れることができないものであ る。それらは法的権利からなる一例えば、相続財産、用益権、各種の契約上の 債権債務などである。相続財産が corporeal things を含む可能性があるというこ とは重要ではない。……肝心なことは、現実の相続権が incorporeal であるとい 
12.また、物は corporeal と incorporealに分かれる。13. corporeal things とは接触できる物（tangible）をいう。例えば、土地、奴隷、衣服、金、 銀、およびその他多数の物である。14. incorporeal things とは接触でき ない物（intangible）をいう。すなわち、権利として存在するものがそれ である。例えば、相続財産、用益権、各種契約上の債権債務である。

したがって、corporeal と incorporeal の区別というのは、tangible objects と

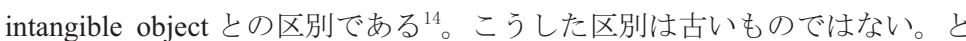
いうのも、 corporalis および incorporalis という言葉は、神聖ローマ帝国の 時代になって初めて登場したものであるからである ${ }^{15}$ 。

それでは、古代ローマの法学者はこうした区別をどこから得たのだろう か ${ }^{16}$ 。この問いは古典学者に向けられた問いである。1つの可能性はス卜 ア哲学 (Stoicism) である17。ストア哲学は法文化を含むローマの文化や哲 学に広範な影響力を有していた。先の区別もストア哲学の思想において見

うことである。…...

14 現代における tangible と intangible との区別は、感覚によって知覚することができ る物と、単に精神の創造物にすぎない物との区別である。ローマ法においては、 tangible とは接触や使用をすることが可能な物を意味したように思われる。P. Warmelo, 'The Institutes of Justinian as Students' Manual' in P.G. Stein and A.D.E. Lewis (eds.), Studies in Justinian's Institutes in Memory of J.A.C. Thomas (London, 1983), 164, 169 を参照

${ }^{15}$ W.W. Buckland, The Main Institutions of Roman Private Law (Cambridge at the University Press, 1931), 91. ブックランドの考察によれば、これらの言葉が法学文献以外で 用いられることは稀であったという。

${ }^{16}$ 現代ローマ法のテキストは、ローマ法の哲学的起源よりも法の内容に関心がある ため、この問題には取り組んでいない。

17 ジョン・オースティンは、こうした区別はストア哲学 (Stoics) および快楽主義哲 学 (Epicureans) から借用したものであると確信している。J. Austin, Lectures on Jurisprudence (5th ed., London, 1885), Lecture XIII を参照。のように考えるのはオー スティンだけではない。この区別がストア哲学に由来することを示唆するものとし T、P. Colquhoun, A Summary of the Roman Civil Law (London, author's preface 1851), vol. 2, 13, section 931 も参照。
いだすことができる ${ }^{18}$ 。したがって、ローマ法上の incorporeal things のカ テゴリーは、 incorporeals に関するストア哲学の観念に由来したものである 可能性がある ${ }^{19}$ 。ストア哲学においては、4つのものが incorporeal である といわれていた。すなわち、時間、空間、空虚さ、lekta（単語や文章の意 味）の 4 つである ${ }^{20}$ 。ストア哲学が徹底的な唯物論（materialism）の哲学で あることを前提とすれば、そのストア派が incorporeal のカテゴリーを有し ていたに違いないということは、一見すると驚くべきことである。神と魂 はストア哲学にとって corporeal の存在物であった。corporeal の存在物の みが実在するもの（real）であった ${ }^{21}$ 。 incorporeal things は実在するもの (existent) ではなく、自存するもの (subsistent) であった。それらは人間の 精神生活によって自存するものであり、また、精神によって corporeal の 世界に重㸚合わされたものであった ${ }^{22}$ 。

唯物論的哲学における incorporeal things なるカテゴリーは、興趣をそそ る並列的配置といえる。その分析的な特徵の 1 つは、ストア派がプラトン (Plato)のように抽象的なイデア (Ideas or Forms) の実在を確約すること なく、普遍的なもの（universals）についての説明をなすことを可能にした 点にある ${ }^{23}$ 。プラトンにとって、数字の 1 、直角度の性質、正義のような

18 ローマの思想や文化に対するストア哲学の影響の一般的な議論として、E.V Arnold, Roman Stoicism (London, 1911, reissued 1958) を参照。

19 我々はストア哲学がこうした区別を有していたということをセクストゥス・エン ピリクスの業績から知っている。Sextus Empiricus, Adversus Dogmatico, ii, 11-13, in Sextus Empiricus (R.G. Bury tr., London, Cambridge, Mass., 1935), vol. 2, 247-249 を参照。 20 lekta という語は、リストの書物では「意味されるもの」(things meant）と訳され ている。J.M. Rist, Stoic Philosophy (Cambridge, 1969), 152-153 を参照。このほか、「表 現されうるもの」 (that which can be expressed)や「意味されるもの」(what is meant) と いう訳もみられる。G. Watson, The Stoic Theory of Knowledge (Belfast, 1966), 41 を参照。 21 一般的な議論に関して、D.E. Hahm, The Origins of Stoic Cosmology (Columbus, Ohio, 1977) を参照。

22 この点に関する議論に関して、G. Watson, The Stoic Theory of Knowledge (Belfast, 1966), chapter 2 を参照。このほか、J.M. Rist, Stoic Philosophy (Cambridge, 1969), chapter 9 も参照。

${ }^{23}$ ストア哲学が普遍的なものについての理論を有していたという議論として、D. 
道徳的用語といった普遍的なものは、永遠不変のイデアとして実在するも のであった。一方、ストア哲学の形而上学の理論においては、特殊なもの (particulars) のみが実在するものであった。普遍的なものは incorporeal things として自存する (subsist) 勝手のよいフィクション、つまり本質的に は観念的な虚構であった。

現代の知的財産権は、私人間の一連の関係を構成するだけでなく、一定 の物 (thing) に対寸る財産権の付与に関連しているということを、我々は 心に留めておかなければならない。しかし、この物の性質は何であろうか。 それは物質的な対象ではありえない。というのも、すべての法学部生が教 わるように、私がある本の物質的複製物を所有しているという事実は、私 がその本の著作権を所有しているということを含意しないからである。さ らにいえば、私は物質的な複製物を所有していなくても、その本の著作権 を所有することはできるのである（例えば、私が書いて送った手紙は他の 誰かにより所有されている)。知的財産権を認めることによって、法は「幽 霊のような」実体 ('spooky' entities)、つまり普遍的なものを認めざるをえ ないのであろうか。あるいはストア哲学の思想は、incorporeal things に対 する財産権について、より合理的な説明を提供しうるだろうか。

最も興味深いストア哲学の incorporeal のカテゴリーは、 lekta (意味) の カテゴリーである。意味は表現可能なものであると考えられる。もっとも、 文書やスピーチにおける物質的な文章表現、例えばメモ帳に記された言葉 や演劇の話し言葉などと混同してはならない。lektaは、その物質的な表現 やコミュニケーションとは論理的に異なる、明示された意味である。 lekta は incorporealsであるので、この世界では活動しえない。lekta は因果的に 不活性なものである。しかし、意味はいったん人々の信念の一部を形成す ると、因果的要素となりうる ${ }^{24}$ 。incorporeal の表現可能なものが人の信念 に入り込む段階では、それは corporeal の力となる。したがって、ここに incorporeal things の法的カテゴリーに関する形而上学的性質についての 1 つの見方が存在する。著作権であれ、特許権であれ、意匠権であれ、保護

Sedley, 'The Stoic Theory of Universals' in R.H. Epp (ed.), Recovering the Stoics, XXIII, Supplement, Southern Journal of Philosophy, $87-92$ (1985) を参照。

${ }^{24}$ F.H. Sandbach, The Stoics (London, 1975), 92.
対象に関する何らかの具体的な明確化 (specification) が存在して初めて、 知的財産権の主張をなすことが可能となるということである。この明確化 プロセスは、一定の形式をともなう場合（例えば、特許権の登録）もあれ ば、形式をともなわない場合（トレード・シークレットの保護対象となり うる情報の単なる創出）もある。この保護対象に関する明確化は、2つの 役割を果たしている。1つは、意味を表すもの（signifiers: 物理的な表現 物) の創出である ${ }^{25}$ 。もう 1 つは、ストア哲学の言葉でいう「表現可能な もの」（an expressible）の創造に相当する、具体的な意味をもった実体（an entity）の創出である。表現可能なものは抽象的な実体であり、勝手のよい 観念的なフィクションでもある。それは、精神の構成物として自存する。 abstract object は corporeal の世界では存在しない。しかし、いったん abstract object が具現化された信念となることで corporeality（有体性）を獲得する と、少なくともストア哲学の物のスキームでは、人々の社会的生産関係に おいて因果的役割を果たすことが可能となる。それと同時に、 abstract object は人間の行動に影響を与えることから、法的規制の潜在的な候補と なるのである。

要約すると、1つの考え方は、精神の構成物が知的財産関係の本質であ るというものである。換言すれば、知的財産権は我々の精神の投影に対す る権利であるという見方である。ほかの選択肢は、これらの abstract things に関して、ある種の実在論的（realist）な説明を採用することである。手短 にいえば、この見方は、 abstract entities は法律書籍やテニスボールのよう な実在する実体であるという主張をともなうだろう。後者の実在論的な立 場に従えば、abstract objectsに対して、独立した存在論的（ontological）な 地位が割り当てられる必要があり、さらにはその存在に関する内在的な説 明（アリストテレス派）か、超越的な説明（プラトン派）かのいずれかの 説明が行われる必要があろう。どちらの説明も哲学的基盤を有するが、こ うした abstract objects に対する実在論的な見方は、知的財産法を形而上学 の世界にはるか深くまで入り込ませることになる。そのため、知的財産法 は、観測不可能な実体に関する独立した存在を深く考慮しなければならな

${ }^{25}$ G. Verberke, The Presence of Stoicism in Medieval Thought (Washington, D.C., 1983), 22-33 を参照。 
いのである。

ローマ法は、res incorporales というカテゴリーを創りだすことで、財産 法を形而上学の分野に直接植えつけた。そしてすぐ後でみるように、英国 法は、英国財産法に非常に柔軟なカテゴリーをつけ加えるために、この res incorporales のカテゴリーを利用したのである。しかし叙述を進める前に、 ここでガイウスやユスティニアヌス (Justinian) における incorporeal things の概念が法的権利に言及している点について明らかにする必要がある。ガ イウスやユスティニアヌスは、権利（rights）という語を、我々が一般に考 えるところの財産権のみならず契約上の権利を含むものとして使用して いる。ユスティニアヌスから強く示唆されるものは、incorporeal things は corporeal の対応物を有しているということである。つまり、incorporeal things は corporeal objects と強い関連性があると考えられているのである。 英国財産法において incorporeal rights と incorporeal objects（つまり我々が abstract objects と呼ぶもの) との結びつきが前面に現れるようになったのは、 多様な知的財産の形態が債権的財産 (chose in action) として分類され、動 産 (chattel) における財産権と注意深く区別されたときであった ${ }^{26}$ 。知的財 産権は incorporeal things であるが、次第に abstract objects と関連した incorporeal rights を意味するようになったのである。

まさに出発点から、 incorporeal things のカテゴリーは法的曖昧さを生み だしている。ガイウスは『法学提要』において、契約上の債権債務関係を ある箇所では res incorporales に含めたり、別の箇所では含めなかったりし ている ${ }^{27}$ 。上述のような区別に基づく場合、dominium（所有権）は権利と関 係しており、権利は接触しえないものであることから、physical objectsに

26 英国法において、特許は債権的財産 (chose in action) である。In re Heath's Patent [1912] W.N. 137 を参照。この権利は、特許に基づいて製造される物理的な物に対寸 る所有権とは完全に切り離されたものである。Edwards \& Co. v. Picard [1909] 2 K.B. 903, 905 を参照。

${ }^{27}$ W.W. Buckland, A Text-Book of Roman Law from Augustus to Justinian (3rd ed., revised by Peter Stein, Cambridge, 1963), 186 を参照。ガイウスがこの区別を必ずしも徹底し ていなかったことに関しては、R. Zimmermann, The Law of Obligations (Cape Town, Wetton, Johannesburg, 1990), 26 在参照。
おける dominium とは res incorporales であると予想する者がいるかもしれ ない。しかしながら、ローマ法の研究者が頓に指摘しているように、 dominium は res corporales のカテゴリーにおいてみられるものである28。 こでは、客体が所有権 (ownership) に代用されている、あるいは、おそら く客体と所有権は代替物とみなされているということであろう ${ }^{29}$ 。近代口 一マ法の研究者は、その論理的欠陥を指摘する以外には客体と所有権との 区別に対してそれほど注意を払わなかった ${ }^{30}$ 。このような状況は、19世紀 の法学者オースティン (Austin) には我慢がならなかったようである。オー スティンは、当該区別を、「不完全なものであるか、さもなければ矛盾に 満ちたものである」と述べて、全く役に立たないものとして否定寸る ${ }^{31}$ 。

ローマ財産法体系は客体と所有権とを融合させているが、通行地役権の ような他の権利は、もはや実際の通行路として具体的に捉えられているわ けではなく、intangible rights としてみなされている。一部の著者は、

${ }^{28}$ W.W. Buckland, A Text-Book of Roman Law from Augustus to Justinian (3rd ed., revised by Peter Stein, Cambridge, 1963), 186.

${ }^{29}$ ニコラスは、 corporeal thing のみ所有することができるのであるから、所有権と 所有権の客体とを明確に区別する必要はないと示唆する。その結果、客体と所有権 とは相互に取り替え可能な用語としてみなされるようになる。B. Nicholas, An Introduction to Roman Law (Oxford University Press, 1962), 107 を参照。

30 この区別は論理的なものではないといわれている。なぜなら、それは所有権と所 有権の客体とを同一視しているからである。B. Nicholas, An Introduction to Roman Law (Oxford University Press, 1962), 107 を参照。その他、H.F. Jolowicz and B. Nicholas, Historical Introduction to the Study of Roman Law (3rd ed., Cambridge, 1972), 412-413; W.W. Buckland, A Text-Book of Roman Law from Augustus to Justinian (3rd ed., revised by Peter Stein, Cambridge, 1963), 185-186; W.W. Buckland, The Main Institutions of Roman Private Law (Cambridge at the University Press, 1931), 91-92 も参照。

${ }^{31}$ J. Austin, Lectures on Jurisprudence (5th ed., London, 1885), Lecture XLVI, 777. オー スティンの非難は、ローマ法において corporeal things の意味が、知覚で察すること ができる対象に加えて、行為 (acts) や不作為 (forbearances) にまで拡大されている ことに基づいている。もし不作為が corporeal の対象の一部を構成するとすれば、 tangible と intangible とが同列に抩われることになって、矛盾が存在することになる。 もし不作為が corporeal の対象の一部でないとすれば、区別する対象がなくなってし まうとオースティンはいう。 
corporeal / incorporeal の区別を、古代の法学者の見解が一般に大いなる抽 象化の傾向を示していたという主張を裏づけるために用いる ${ }^{32}$ 。この主張 が正しいのかどうかは別の問題であるが、我々は次のことを指摘できよう。 すなわち、財産法の文脈において res incorporales というカテゴリーが認識 され、一部の権利が intangible として形式上分類されていることは、少な くとも財産の概念についてより抽象的な法的思考様式が発展寸る可能性 を残すものといえるだろう。

corporeal / incorporeal の区別は、11世紀ボローニヤにおいてイルネリウ

ス (Irnerius) とその門下生が古代ローマ法の再発見およびリバイバルを成 し遂げるまで休止状態にあった。しかしここから、ローマ法の新たな征服 の旅が始まったのである。ローマ法は、さまざまな時代において、またさ まざまなレベルにおいて、ヨーロッパの法制度に入り込んだ。 res incorporales といらカテゴリーも、その未開拓の可能性を秘めながら、大陸法お よびコモン・ローの双方の法律用語に入り込んだ゙3。そして incorporeal things は、より厳密にいえば incorporeal things というカテゴリーは、苦労 しながらも、債権的財産という同様に曖昧な法的カテゴリーと融合するこ とによって、辛うじて英国法に紛れ込んだのである ${ }^{34}$ 。何にもましてこの

${ }^{32}$ H.F. Jolowicz and B. Nicholas, Historical Introduction to the Study of Roman Law (3rd ed., Cambridge, 1972), 412 を参照。しかし、反対の見解として、F. Schulz, History of Roman Science (Oxford at the Clarendon Press, 1946), 130-131 を参照。

33 ユスティニアヌス『法学提要』が英国に与えた影響については、A. Watson, 'Justinian's Institutes and some English Counterparts' in P.G. Stein and A.D.E. Lewis (eds.), Studies in Justinian's Institutes in Memory of J.A.C. Thomas (London, 1983), 181-186 を参 照。

34 英国財産法においては、不動産と人的財産とで区分がなされている。不動産は土 地の利益と結びつけられているのに対し、人的財産は不動産以外の財産を指すもの として消極的に定義されている。人的財産はさらに、不動産に関する人的財産 (chattels real) と不動産に関係しない人的財産 (chattels personal) とに分類される。不 動産に関する人的財産は、不動産賃貸借が歷史的な理由から人的財産に分類された ことに基づく特異なカテゴリーである。不動産に関係しない人的財産はさらに、動 産と債権的財産とに分類される。そしてこの後者のカテゴリーに、特許や著作権を 始めと寸る多くの知的財産制定法が含まれるのである。制定法は一般に、その用語
債権的財産という人的財産に関するカテゴリーは、中世における財産概念 に対する態度を特徴づけた「物に類似した性質」（thinglikeness）をいつで も践失寸ることのできる状態の整ったものであった。そしてその結果、財 産とは物ではなく、人と人との間の一連の関係であるという現代法学の発 見への道が開けたのである。

知的財産権を債権的財産と呼ぶことで、直ちに問題が解決するわけでは ない。その理由を簡潔にいえば、債権的財産という概念は、構成メンバー を自ら主体的に選択することができるような定義ではなく、その構成メン バーを記述することよって初めて理解しうる集合にすぎないものである、 と法理論学者によって結論づけられていたからである ${ }^{35}$ 。債権的財産の説 明として、債権的財産とは動産 (chose in possession) ではなく、金銭債務 のように訴訟によって回収が図られるものであるという説明がなされる ことが多い活。しかし、すべての訴権（right of action）が債権的財産である わけではない。債権的財産は、法的基礎と関連した曖昧さの程度に関して、 通常以上の曖昧さを含んでいるように思われる。占有を有しない動産所有 者のような、一見すると単純なケースの分類がこれまで議論の対象となっ てきた ${ }^{37}$ 。corporeal / incorporeal の区別は、債権的財産のカテゴリーにおい て認識されているが、明確性という点ではさしたる貢献はない。債権的財 産は intangible property、すなわち物理的な占有を獲得することでは請求が できないものと関連しているのに対し、動産は corporeal things ないし tangible things と関係しているといわれている38。

に関する法的に確立された意味に基づいて、関連する権利を人的財産に分類してい る。オーストラリアの例として、1990年特許法13条 (2)、1968年著作権法196条 (1)、 および1994年植物育成者権法 20 条を参照。英国人的財産法の議論に関しては、A.P. Bell, Modern Law of Personal Property in England and Ireland (London, Edinburgh, 1989) を参照。オーストラリアの議論に関しては、 J.W. Carter et al, Helmore Commercial Law and Personal Property in New South Wales (10th ed., Sydney, 1992) を参照。

${ }^{35}$ O.R. Marshall, The Assignment of Choses in Action (London, 1950), 33.このほか、債 権的財産に関する 10 個の多様な定義が掲載されている同書 $6 \sim 8$ 頁も参照。

${ }^{36}$ Halsbury's Laws of England (4th ed.) vol. 6, 2, para. 1.

${ }^{37}$ O.R. Marshall, The Assignment of Choses in Action (London, 1950), 8-16 を参照。

${ }_{38}$ A.P. Bell, Modern Law of Personal Property in England and Ireland (London, Edin- 
なぜ知的財産権は債権的財産とみなされるようになったのだろうか。そ の答えは、論理の当てはめというよりも、偶然や歴史、英国法制度の内部 力学といったものと関係がある。この分類の過程は長期間に及ぶものであ った。というのも、英国では、例えば著作権は本当に債権的財産かどうか といった論争が19世紀の初頭においてもなお静かに進行していたからで ある ${ }^{39}$ 。

コモン・ローの歴史の初期においては、債権譲渡を禁止するルールが存 在していた ${ }^{40}$ 。その主な理由は、債権は譲渡に相応しくないほど高度に人 的な債務であると考えられていたからであり、また、いずれにせよ債権の 譲渡が必要以上に訴訟を引き起こす可能性があるからであった ${ }^{41}$ 。しかし、 特許や著作権が登場した時期には、債権の非譲渡性ルールはエクイティ裁 判所によって実質的に衰退させられていた。このことは、特許や著作権を 債権的財産のカテゴリーに当てはめることを容易にした。また、これらの 財産形態が譲渡可能であることは商業上の要請でもあり、譲渡禁止ルール は徐々に衰退していった。特許や著作権の債権的財産としての分類に影響 を与えた別の要因は、その incorporeal な性質であった ${ }^{42}$ 。

そうだとすると、状況は全く違ったものとなった可能性もあるのである。 例えば、ホールズワース (Holdsworth) は、もしエクイティ裁判所が債権譲 渡を禁止するルールの結論を修正しなければ、知的財産権は無体法定相続

burgh, 1989), 21-22

${ }^{39}$ H.W. Elphinstone, 'What is a Chose in Action?', 9 Law Quarterly Review, 311 (1893); C. Sweet, 'Choses in Action', 10 Law Quarterly Review, 303 (1894); F. Pollock, 'What is a Thing?', 10 Law Quarterly Review, 318(1894); S. Brodhurst, 'Is Copyright a Chose in Action?', 11 Law Quarterly Review, 64 (1895); T.C. Williams, 'Property Things in Action, and Copyright', 11 Law Quarterly Review, 223 (1895); C. Sweet, 'Choses in Action', 11 Law Quarterly Review, 238 (1895) を参照。

${ }^{40}$ O.R. Marshall, The Assignment of Choses in Action (London, 1950), chapter 3 を参照。

${ }^{41}$ 訴訟幇助 (maintenance) に対する異議として知られている。Lanpet’s Case (1612) 10 Co. Rep. 46b at 48a; 77 ER 994 at 997 を参照。債権譲渡は、訴訟幇助つまり干渉者 による訴訟の推進を助長するだらうと考えられていた。訴訟幇助は犯罪となり、か つ不法行為が成立した。

${ }^{42}$ E. Jenks, A Short History of English Law (6th ed., London,1949), 281 を参照。
産 (incorporeal hereditament) として扱われていたかもしれないと主張す る ${ }^{43}$ 。これに対しては、知的財産権が債権的財産に分類されるか、それと も無体法定相続産に分類されるかということは、どちらも財産カテゴリー なのであるから重要な問題ではない、という見方もありえよう。しかし、 おそらくは各カテゴリーが表す抽象性のレベルにおいて相違が存在する。 ブラックストーン (Blackstone) が列挙する無体法定相続産（例えば、地役 権や採取権）は、強い属地性を有している ${ }^{44}$ 。大部分の無体法定相続産は、 何らかの形で境界を有する不動産と関連している。これに対し、債権的財 産は、他の財産形態との関係で存在する属地性や有体性の痕跡一ポロック （Pollock）が英国財産の「物に類似した性質」と呼んでいるもの一を消失 するのにより適している。こうした新たな形態の人的財産は、慣習的形式 および封建的形式の財産にみられるような強い態様で共同体を拘束しな いことから、ある意味では人的側面の弱いものであった。しかしこれらの 新たな形態は、所有者と第三者との匿名的かつ非個人的な連関、寸なわち 20 世紀において通常の財産関係の属地性を打ち破って真のグローバル化 を実現した連関を可能とするものであった。

債権的財産の重要性の高まりを通じて生じた心理的および概念的変化 の大きさは、過小評価されるべきではない。メイトランド (Maitland) とポ ロックはともに、英国物的財産権法 (real property law) の大部分は、中世 においては権利の移転と物の移転とを区別することができなかったとい うことを踏まえれば容易に理解できると主張している ${ }^{45}$ 。通行地役権のよ うな無体法定相続産の場合でさえ、「物類似の」性質をそれらに起因する ものとみなし、その財産の性質を土地との類比で説明する傾向があった。 例えば、借地人による新権利者の承認（attornment）のような慣行は、無体 法定相続産の移転を取り囲むものであるが、それはこうした法定相続産が

${ }^{43}$ W.S. Holdsworth, 'The History of the Treatment of Choses in Action by the Common Law', 33 Harvard Law Review, 997(1920).

${ }^{44}$ Sir William Blackstone, Commentaries on the Laws of England (1765; 1783 ed., reprinted by Garland Publishing, New York, London, 1978), Book II, chapter 3.

${ }^{45}$ F. Pollock and F.W. Maitland, The History of English Law (2nd ed., Cambridge at the University Press, 1898, reissued 1968), 124-125. 
実際には権利ではなく物としてみなされていたということを明らかにす るものであるとメイトランドは示唆している ${ }^{46}$ 。

英国法は、ローマ法の incorporeal thing のカテゴリーを債権的財産のカ テゴリーと結びつけることによって、非常に柔軟な人的財産概念を創出し た。英国法が柔軟である理由は、まさに正確に特定された一定の属性によ ってその拡張が制限されていなかったからである。その非限定性（indefiniteness）は、財産制度の機能的強みの源泉であった。その結果、英国法は 市場や社会関係の多様な分野にまで広がることができたのである ${ }^{47}$ これ は大陸民事法制度には実際に相当するものがない概念であった ${ }^{48}$ 。

最後に 1 つ検討しなければならないことがある。ある見解によれば、 我々がみてきた incorporeal things の発展に関する短いストーリーは、財産 法はその長い発展過程において次第に非物質化され、一層抽象的なものと なり、ポロックの言葉を用いるならば、その「物に類似した性質」を衰失 してきたという考え方を支持するものであるように思われるかもしれな い。このような結論を下寸のは簡単であるが、しかし果たして我々はこの ような結論を下寸べきであろうか。我々が述べたストーリーにおける出来 事というのは、現実の問題に対する現実の解決策を構築するためにローマ 法上のカテゴリーが英国法学者によって用いられたということである。ア イディアの豊富な人というのは、広い意味では資産 (assets) を有している のである。そうした人が市場経済で生計を立てることを可能とするために は、その intangible assets (無形資産) が商業的に利用可能となるよう、そ れらの資産は何らかの方法で財産権として承認されなければならない。こ のような目的にとって極めて重要な概念装置の一部がローマ法によって

${ }^{46}$ F.W. Maitland, 'The Mystery of Seisin' in Select Essays in Anglo-American History (edited by a committee of the Association of American Law Schools, Cambridge at the University Press, 1909), 591-610.

47 非限定性こそが財産の本質であるとオースティンは主張する。しかし彼は、それ があたかもすべての法域の財産に当てはまるかのように記述している。J. Austin, Lectures on Jurisprudence (5th ed., London, 1885), Lecture 48 を参照。

48 コモン・ロー制度と大陸法制度との財産に対するアプローチの相違に関する優れ た議論として、'Introduction' by O. Kahn-Freund (ed.) in K. Renner, The Institutions of Private Law (A. Schwarzschild tr., London, 1949) を参照。
もたらされた。英国のコモン・ローは、そのプラグマティズムで有名であ るが、危険を冒して形而上学領域の奥深くにまで立ち入り、知的財産の abstract objects を incorporeal things のリストにつけ加えたのである。そうす ることで、知的財産は material objectsにまでその手を伸ばした。芸術家、 作家および発明家は、この世界で経済的に生存していくためにはその intangible assets を material assets (有形資産) に転換しなければならない。 いったん知的財産法が abstract objectsにおける財産を承認した後は、物質 世界における財産関係を支配する物質性（materiality）の重要性がより一 層強まったのであって、弱まったのではない。その重要性が強まった理由 は、abstract objects を通して、ますます多くの material objectsが、数にお いても種類においても、個人財産所有者の影響下におかれうるようになっ たからである。abstract object は material objectを支配する1つの方法とな つた。1つの特許は無数の physical objectsに関連しうる。知的財産権の corporeality は、法的にいえば、はるか遠くにあるのではなく、abstract object に物質性を課すさまざまな要件となって現れるのである ${ }^{49}$ 。

\section{知的財産権の正当化}

知的財産権の場合、abstract objects は私人間の財産関係を媒介する「物」 (things) である。利用による枯渴を観念しえない資源の最適な例であるも のに財産権を創設することを正当化する根拠は、結局のところ何であろう か。tangibles の場合には、人はその物を利用することで他者から物を奪う ことができる。しかし、abstract objectsの性質はその物を同時に利用する

49 例えば、特許出願においては当該発明について説明し定義した明細書を添付する 必要がある。発明自体は、物質を喚起するような用語で定義されることが多い。専 売条例 (Statute of Monopolies) は、「いかなる態様のものであれ、新たな製造物」(any manner of new manufactures) に言及している。この文言は1990年オーストラリア特 許法にも継承されており、同法18条 (1) (a) は発明を「専売条例 6 条の意味における 製造の態様のもの」（a manner of manufacture within the meaning of section 6 of the Statute of Monopolies) と定義している。著作権法も一般に著作物に関して物質的形態 の要件を課している。 
ことを認めるため、利用による abstract objects の剥奪という事態は生じえ ない。

英国法は、特許権および著作権の文脈において、こうした正当化根拠の 問題に最初に対峙しなければならなかった。これらの各文脈において、こ の問題に対する解答は、キリス卜教の影響を強く受けた法的伝統の中で、 そしてまた自然法上の財産理論の影響を受けた言説の中で提示された。こ のような伝統の中で、正当化根拠の問題は特許権と著作権とで異なる議論 が行われた。これらの主張を説明するために本書では、著作権に関しては アン法と Millar v. Taylor 事件の議論に、特許権に関しては専売条例 (Statute of Monopolies）と The Case of Monopolies の議論に、それぞれ限定して考察 を行うことにしたい50。もちろん、これだけの事例では数が少ないという ことは認めざるをえないが、しかしそうはいっても、裁判例や制定法の中 には当時の広範な法的世界について多くのことを明らかにするものもあ る。本書で取り上げる 2 件の裁判例は、英国法において最も有名なもので あって、哲学的議論に富むものであり、正当化根拠の問題を解決するため に用いられた法的準拠枠を明確に提示するものである。

\section{著作権}

著作権から始めることにしよう。英国著作権の歴史については数多くの 優れた文献が存在する。したがってここでは、我々が分析対象として選択 した素材に取りかかるのに先だって、英国の著作権史をごく簡単に眺める 程度にとどめたい ${ }^{51}$ 。

${ }^{50}$ Millar v. Taylor (1769) 4 Burr. 2303, 98 E.R. 201; Act of Anne 8 Anne, c. 19 (1709); The Case of Monopolies (1602)11 Co. Rep. 84b, 77 E.R. 1260: Statute of Monopolies $21 \mathrm{Jac} 1 \mathrm{c}$. 3 (1623).

51 第一次資料に関する優れたソースは、E. Arber (ed.), A Transcript of the Registers of the Company of Stationers of London 1554-1640 A.D. (London, 1875-94, privately printed, 5 volumes) である。専門的なテキストの例としては、C. Blagden, The Stationers' Company: A History, 1403-1959 (Cambridge, 1960); L.R. Patterson, Copyright in Historical Perspective (Nashville, 1968); G. Putnam, Books and their Makers During the Middle
15世紀イングランドにおける書籍の印刷および出版は、正式には書籍出 版業者（the Stationers）として知られていた手工業者ギルド（a craft guild） によって営まれていた。すべての手工業者ギルドと同様に、書籍出版業者 は、独占利益に強い関心があり、またそれと同じくらい競争への恐怖心を 抱いていた。このように独占利益への関心と競争への恐怖心とが組み合わ さった結果、書籍出版業者のギルドのメンバーは、やがて 1557 年に法人化 栜許状 (a royal charter of incorporation) の取得に向けて請願を行うに至っ た ${ }^{52}$ 。メアリー女王 (Queen Mary) は、書籍出版業者の請願を喜んで受け入 れた。印刷の統制権限を書籍出版業組合 (Stationers' Company) に付与寸る ことは、扇動的、異端的情報の拡散を統制しうる別の手段をもたらすこと になったからである（もっとも、国王が早い時期から書籍出版業者を利用 しようとしたのではなく、むしろ拷問や殺害のようなより手荒い手段に頼 ることを好んだ点は指摘しておく必要がある $)^{53}$ 。

二組の自己利益間に相補関係がみられたことを背景として、出版業を統 制するために特権を利用寸るケースが16世紀イングランドにおいて現れ た。すなわち、一方で、国王はその政治的安定にとって印刷の支配権限が 不可欠であると考えていたのであり、他方で、書籍出版業者はロンドンを 中心とする彼らの独占を維持し、地域的に、さらには国境を越えてスコッ トランドにまで彼らの影響力を拡大寸るための手段として、特権制度とみ なしていたのである。著作権の歷史におけるこの段階では、著作者はほん

Ages 1476-1600 (New York, 1962); H. Ransom, The First Copyright Statute (Austin, 1956) がある。

${ }^{52}$ E. Arber (ed.), A Transcript of the Registers of the Company of Stationers of London 1554-1640 A.D. (London, 1875-94, privately printed, 5 volumes), vol. 1, xxviii に再録さ れている。1557年法人化栜許状は、次のような冒頭で始まる。

「国王と王妃は、……汝らのことを知っている。つまり国王と王妃は、いくつ かの中傷的かつ異端的な書物や詩および論文が、さまざまな挑戦的で悪意に満ち た離教的かつ異端的な人々によって日々出版され配布されており、臣民や家臣を、 国王と国家の威信に対する反逆と不服従一と唆すのみならず、聖母教会の真実か つ健全なカソリックの教義に対して、それを作り変え変革しようという、最も大 それた憎むべき異端へと唆すということを考慮し、明白に把握している。」 ${ }^{53}$ Ibid at xxvii. 
の脇役にすぎなかった。中心的役割を演じたのは国王と印刷業者であり、 その両者とも著作者の権利や経済および文化にとっての複製権の価值に は特に関心を示さなかった。著作者が個人的な特権を手に入れるほど恵ま れている場合を除いては、著作者の立場は弱く、もし原稿が公に配布され ることに著作者が同意したとすれば、書籍出版業組合のメンバーが当該原 稿の著作権を登録し、それを利用することを禁止するのが不可能なほどで あった。書籍を印刷する権利は、著作者にではなく、特定の作品を登録す る書籍出版業組合のメンバーに帰属していた。

この特権制度は結局破綻した。その理由の一端は、出版産業の至るとこ ろで特権が不均等にばらまかれており、同産業において収益の高い大きな シェアをもつ人々と、同産業の縁で生き延びている人々との間で、軋䡚を 生みだしたという点に求めることができる。1709年のアン法は、特権制度 に取って代わるものであった。アン法は、著作権に対する公共利益の位相 の到来を告げるものであったことから、画期的な制定法であった。アン法 の前文は、著作権を「学問の奨励」(Encouragement of Learning) と結びつ けた。アン法は、著作権の保護期間を制限することによって、パブリック・ ドメインの存在を承認した ${ }^{54}$ 。アン法は、まだ印刷されておらずこれから 出版される書籍に関して、著作者に「印刷の独占的自由」（sole Liberty of printing）を与えた。アン法全体の趣は、道具的かつ実用的であった。著作 権の役割は著作者の創作を促すことであり、それによって学問を奨励し、 学問に新たなものをつけ加えるという、より大きな目的に奉仕することで あった。既に出版された書籍に対寸る書籍出版業者の独占的な支配は、ア ン法が既存書籍に対する保護を［1710年 4 月 10 日から］21年間に制限する ことによって排除された。書籍の価格統制条項も導入され、大学の諸利益 は明確に守られた。

アン法の到来は、書籍出版業者にとって大いなる歓喜の種では決してな かった。その後、数十年にわたり、アン法は英国裁判所において検証が行 われた。18世紀におけるこれらの裁判例は、非常に現代的な意義を有して いる。というのも、著作者がアン法制定後も存続する権利をもつのかどう

${ }^{54}$ L. Ray Patterson and Stanley W. Lindberg, The Nature of Copyright (Athens, London, 1991), 29-31.
かを判断する際に、裁判所は著作権保護の根拠について真正面から取り組 む必要に迫られたからである。その結果、裁判所は哲学的な領域へと立ち 入らざるをえなかった。書籍出版業者による訴訟は、書籍の財産権あるい は「文芸的財産権」(literary property) に関する広範な社会的論争の一部で あった。この論争は、17世紀後半から18世紀にかけての英国史において、 最も長期にわたる、最も鋭く意見の対立した論争の 1 つであった ${ }^{55}$ 。実際 出版業界に利害関係をもつ人々だけでなく、一般の知的サークルに属する 人々までもがこの論争に加わったのである。数多くのことが問題とされた。 一部の人々にとって真の問題はアイディアの普及に対する統制にあった ${ }^{56}$ 法廷における議論は、著作者が自己の著作物を出版した後においてコモ ン・ロー上の著作権（common law copyright）は存在するのかどうかという ことを根本的に問うものであった。書籍出版業者は、独占状態が崩れるの を嫌がり、次のように主張した。すなわち、コモン・ローはいかなる制定 法とも独立に著作者に対して永久の著作権（書籍出版業者が著作者から獲 得することのできる著作権）を付与するものであり、このコモン・ロー上 の著作権は出版およびアン法のいずれの影響も受けないものである、と。 結局、書籍出版業者のこうした主張は受け入れられなかったが、彼らは法 廷においてそうした主張を展開したので、英国の裁判官にとっては、著作 物における著作者の権利の性質について意見を述べる機会が与えられた。 そして最終的には、Donaldson v. Beckett 事件において、(6 対 5 という) 僅 差の多数意見ではあったが、アン法はコモン・ロー上の著作権を廃止した ものであるという判断を下したのである ${ }^{57}$ 。本件はこの問題について裁判

55 この論争に関連する書籍のタイトルは、S. Parkes (ed.), The English Book Trade 1660-1853 (New York, London, 1974) の中の 42 冊もの巻に再録されている。とりわけ 興味深いのは、以下のタイトルである。すなわち、“English Publishing, the Struggle for Copyright and the Freedom of the Press: Thirteen Tracts, 1666-1774'; 'The Literary Property Debate: Seven Tracts 1747-1773'; 'The Literary Property Debate: Six Tracts 1764-1774'; 'The Literary Property Debate: Eight Tracts, 1774-1775’ である。 56 こうした影響に対する裁判所の見解として、Millar v. Taylor 98 E.R. at 229-250 に おけるイェーツ裁判官の反対意見を参照。

${ }^{57}$ (1774) 4 Burr. 2408, 98 E.R. 257. 本件において貴族院はそもそも著作者がコモ ン・ロー上の著作権を保有寸ることについて支持しなかったとする見解として、L 
所の見解が示された最後の裁判例というわけではないが、著作権が制定法 の産物であると考えられるようになる思考の道筋を確立したのはまさに 本判決であった。

それではここで、本節の冒頭で述べた最初の事件の検証に移ることにし よう。1769年の Millar v. Taylor 事件は、Donaldson v. Beckett 事件に先行す るものであり、いろいろな意味で文芸的財産権をめぐる議論の本質を捉え た事件である。Millar v. Taylor 事件は、次の 2 つの問題を提起した。すな わち、著作者はコモン・ロー上の複製権（a right of copy at common law）を 有しているだろうか。もし有しているとすれば、このコモン・ロー上の複 製権はアン法によって剥奪されたのだろうか。本件における原告ミラーは、 「四季」（The Seasons）という詩の登録著作権の保有者であった。被告テイ ラーは、ミラーの許諾を得ていなかったが、当該詩の複製物を保有してい たので、それらを販売することができた。アン法によって与えられた保護 期間は満了していた。ミラーが勝訴する唯一の望みは、アン法の影響を受 けないコモン・ロー上の著作権が存在することを証明することであった。 ミラーはこうした証明に成功した。 4 人中 3 人の裁判官は、ミラー勝訴の 判決を下したのである。

コモン・ロー上の著作権を支持する判断を下した裁判官からは、多様な 正当化の議論が提示された。マンズフィールド主任裁判官 (Mansfield CJ) は、出版される前であれ後であれ著作者の権利の淵源は同じであると述心 たうえで、権利の基礎は正義にあると主張する。すなわち、「著作者は自 己の創意と労働に関する金銭的利益を手に入れるべきだとすることが正 義にかなう。そしてまた、他者は同意なくして著作者の名前を使うべきで はないとすることが正義にかなう。」と主張するのである58 ほ も正義に訴えかけているけれども、彼らは追加的な論拠を提示している。 ウィレス裁判官（Willes J) は、道具的議論を提唱した。彼は財産権をイン センティヴと結びつけて考える。自ら種をまかなかったものから他者が利 益を得ることができるのだとすれば、「そのような自然法上の正義には賛

Ray Patterson and Stanley W. Lindberg, The Nature of Copyright (Athens, London, 1991), $36-46$ を参照

5898 E.R., at 252.
同しない」と認めたうえで、ウィレス裁判官は次のような議論を提示する。 いわく、「いかなる国においても、学識ある者たちの学問や骨の折れる研 究を奨励することは賢明である。最も簡単で最も平等な方法は、彼らに自 己の成果に対する財産権を保障することである。 $\rfloor^{59}$ 正当化根拠の第 3 の 立場は、アストン裁判官によって提示された。アストン裁判官は、著作者 は知的労働の成果を所有するということに権利の存在の基礎をおく ${ }^{60}$ 。 の見解は、なぜ労働がこうした財産権の付与といった性質をもつべきなの かという問いを引き起こす。この点に関するアストン裁判官の論拠は明ら かではないが、後に、財産権の侵害は自然の理性に反するという自らの主 張をサポート寸るために、自然法を引用している ${ }^{61}$ 。アストン裁判官の分 析は、明らかにロック（Locke）の系譜に属するように見受けられるし、実 際、彼は『統治二論』第二篇 (Book II of the Two Treatises of Government) に おけるロックの所有権に関する議論に触れている。もっとも、それはロッ クの所有権に関する議論が文芸的財産権とは関連しないものであると述 べるためにすぎない 62 。それにもかかわらず、著作者の知的労働は財産権 を生みだすというアストン裁判官の議論は、次章でみるように、相当程度、 ロックの所有権の起源に関する分析と類似している。

要約すれば、Millar v. Taylor 事件においては、正当化根拠に関する $3 つ$ の立場がみられる。我々はそれらを正義による正当化、インセンティヴに よる正当化、および自然権による正当化と呼ぶことができる。これらは明 らかに独立している。財産権が創作のインセンティヴであるということに ついては否定しながらも、創作者に報いる（reward）ために財産権を創設 することは正義の要請であると主張する者がいるかもしれない。インセン

\footnotetext{
${ }^{59}$ Id., at 218 .

${ }^{60}$ Id., at 221.

${ }^{61}$ Id., at 222.

${ }^{62}$ Id., at 220-221. アストン裁判官がこのように考える理由は、ロックの理論が「生 活必需品」に適用されるものであるからである。さらに、ロック理論のような理論 は、一定の占有行為つまり身体的な接触行為に基礎をおいている。占有は文学的作 品における財産権の獲得にとって関連性を有しないことをアストン裁判官は示唆
} しているようにみえる。 
ティヴによる正当化はその性質上、道具的である。財産権は社会的に有益 な活動を獲得するための梃子である。自然権による正当化は、その望まし さを、自然法の存在とそれを識別することのできる人間の理性の存在に依 存している。これらの正当化根拠は著作権の文脈において裁判官によって 考え出されたものであるけれども、それらは知的財産権の他の分野にも等 しく適用することが可能である。後の章では、これらの正当化根拠のそれ ぞれがより詳細な評価対象となるだろう。ともあれ差し当たっては、Millar v. Taylor 事件の分析を続けることにしたい。なぜなら、財産についての自 然法的思考と著作権との関係について、多くのことを明らかにしているか らである。

Millar v. Taylor 事件の 1 つの興味深い特徵は、各裁判官が自然法上の財 産理論を利用寸る方法がそれぞれ異なっていることである。裁判官は全員 この知的伝統と向き合わなければならなかった。その理由は、1つには、 弁護士がその答弁において相当程度、自然法上の財産理論に依拠している ということが本件から明らかだからである。またもう1つには、自然法上 の財産理論が当時の支配的な伝統であったからである。所有権とその正当 化についての問題に関心がある場合に、現代の評者がこの事件から得られ る 1 つの教訓は、そうした問題の分析結果は、道徳理論の選択にはそれほ ど依存しておらず、むしろ特定の正当化理論が拠って立つ共同体の特徵や 記述に大きく依存しているということである。先の 2 つの判決をより緻密 に検討寸れば、こうした特徵が浮かび上がる。

アストン裁判官とイェーツ裁判官（反対意見を述べた唯一の裁判官）は ともに、グロティウス (Grotius)、プーフェンドルフ (Pufendorf)、ロック らの理論を援用する ${ }^{63}$ 。イェーツ裁判官は、英国人的財産法の発展を自然

63 アストン裁判官は、98 E.R., at 220 において、ロックの The Second Treatise of Government (1690) における所有権に関する議論に明示的に触れている。同裁判官は また、グロティウスの De Jure Belli Ac Pacis Libri Tres (1625) における所有権の起源 に関する議論や、プーフェンドルフの De Jure Naturae et Gentium Libri Octo (1672) に も言及寸る。9 98 E.R., at 220-221 を参照。イェーツ裁判官は、98 E.R., at 231 and 233 に おいて、プーフェンドルフを明示的に援用する。ウィレス裁判官は、「弁護人の創 造力」を用いたものと彼がいうところの形而上学的議論に言及し、「ドングリの所
法と明確に関連づけて考えている ${ }^{64}$ 。しかし、同じ自然法の枠内で考えな がらも、アストン裁判官とイェーツ裁判官は正反対の結論を導きだす。ア ストン裁判官は、著作者は abstract objectsに財産権を有すると結論づける のに対し、イェーツ裁判官は、公表 (publication)によってこの財産権は消 滅すると主張する。両者の間には、自然法に関する知的集成物の用い方に おいて数多くの相違が存在するが、なかでも決定的に重要な相違はそれぞ れの共同体概念の用い方である。アストン裁判官は、著作者が著作物をこ の世にもたらした瞬間から文芸的財産権が著作者に帰属すると主張する。 アストン裁判官はこうした文芸的財産権を、共有状態から始まり一定の占 有行為を通じて個人所有へと至るものと彼がいうところの、 tangible property と対比する。次の一節は、アストン裁判官がなす二種類の財産間 の対比を示している ${ }^{65}$ 。

この種の財産には、占有によって獲得される財産、つまりもともとは 共有のものであり、個人所有のものではないが、しかし個人の一定の 行為を通じて個人所有のものへと変容寸る財産との間において、重要 な相違がある。というのも、この種の財産は原始的には著作者のもの である。したがって、著作者自身の行為またはその完全な同意によっ て明確に共有のものとされない限り、その財産は依然として著作者本 人の所有物であるはずである。

有権を獲得する想像上の態様」を历めかしている。9 98 E.R., at 218 を参照。これはお そらく、ドングリに直接言及するロックの所有権の議論を参考にしたものである ( $\mathrm{J}$ Locke, The Second Treatise of Government (P. Laslett (ed.), Cambridge, 1988), Book II, chapter 5, section 28 を参照)。しかしいかなる場合でも、ウィレス裁判官は、自然法 の伝統についての明示的な議論は physical objects とのみ関連性を有するものであ ると主張して、そうした議論を回避することを選択する。一方、マンズフィールド 裁判官は、自己の結論を正当化するために、自然法の原則や道徳的正義に依拠する。 もっとも、同裁判官は、グロティウス、プーフェンドルフ、あるいはロックの議論 を明示的に引き合いにだすことはしない。

6498 E.R., at 229

${ }^{65}$ Id., at 221. 
上記の主張をなすにあたり、アストン裁判官は、グロティウス、プーフ エンドルフ、ロックのような自然法論者にとって極めて重要な問題に関す る議論を引用している。これらの理論家たちは、私有財産権の発展につい て説明しようとした。神は大地とその内容物を共有のものとして、つまり 共同所有権という形で、原始的共同体に与えたのだろうか。あるいは、こ の付与は単に大地を利用可能にすることだけを目的としており、所有権の 問題は後の段階で人間によって決定すべきものなのであろうか。前者の共 同体構想、つまり積極的共同体 (positive community) は、個人による財産 の取得を他者の同意に大きく依存したものとするだろう。なぜなら、個人 は万人に帰属しているものを取得しようとするからである。これに対し、 後者の共同体構想、つまり消極的共同体 (negative community) は、個人が 労働を通して財産を取得することのできる範囲をより広げるものである。 なぜなら、個人は、万人にその取得が開かれているが、誰か一個人に帰属 しているわけではないものを取得しようとするからである66。ここでは他 者の同意は積極的共同体におけるほど強い役割を有していない。

アストン裁判官は、消極的共同体の擁護者であるプーフェンドルフを肯 定的に引用し、著作者の精神的労働は文学作品における財産権の根拠を与

66 グロティウスは、原始的共同体の性質の問題については若干曖昧である。Mare Liberum においてグロティウスは、その共同所有権の性質を明確にすることなく、 「万人が享受しうる共有の」ものがいくつか存在すると述心゙て話を始める。その後 グロティウスは、原始状態において「共有のもの」とは万人が所有権を共有してい ることではなく、単に所有権が全く存在しないことを意味するにすぎないと示唆し ている。H. Grotius, Mare Liberum (1608; R. Van Deman Magoffin tr., New York, 1916) a 2, and 22-25 を参照。私的所有権の起源および発展に関する議論については、H. Grotius, De Jure Belli Ac Pacis Libri Tres (1625; F.W. Kelsey tr., New York, London, 1964), Book II, chapter 2 も参照。そこでグロティウスは、ユスティヌス（Justin）を引用して、 万物はもともと共有の物であって、全人類の所有にかかる分割不可能な物であった と述べる。グロティウスはこれに続けて、「各人は自己の必需品として欲するもの は何であれ直ちに取得することができる」と主張する。これは消極的共同体と整合 的である。自然法の研究者による消極的および積極的共同体の利用に関しては、 the commentary by K. Haakonssen on Thomas Reid, Practical Ethics (K. Haakonseen ed, Princeton, New Jersey, 1990), 323-326 を参照。自然法における所有理論に関する優孔 た議論として、S. Buckle, Natural Law and the Theory of Property (Oxford, 1991) を参照。
えると主張する ${ }^{67}$ abstract objects が財産となりうるという事実は、アスト ン裁判官にとって問題とならない。なぜなら、アストン裁判官はプーフェ ンドルフに依拠しながら、財産権の対象は時の経過とともに解決されると 主張するからである。換言すれば、自然法原理は、社会がその実定法上の 財産ルールを新たな状況に適合させるために調整することを禁止したり しないのである。発見、発明、および芸術は、財産権の考えられる対象範 囲を拡大したのである。

一方、イェーツ裁判官は、アストン裁判官と同様に自然法理論にみられ る財産権の一般理論に依拠するが、著作者はアン法を超えてコモン・ロー 上の著作権を有しないと説示して、アストン裁判官とは正反対の結論を導 く。abstract objects は占有できないのであるから、占有は当該権利の基礎 となりえない 68 。abstract objects に価值があるという事実によって、当該対 象が個人の財産に変わることはない。なぜなら、「単なる価值は財産を構 成しない」からである ${ }^{69}$ 。イェーツ裁判官がコモン・ロー上の著作権を否 定する理由は、1つには abstract objects の性質に基づいている。すなわち、 イェーツ裁判官が次の一節で明らかにしているように、 abstract objects は 所有することが不可能だからである。

しかし、ここで主張されている財産は全くもって観念的なものである。 つまりそれは、何らの境界や目印をもたず、目にみえる形で占有する ことができるものではなく、財産としての性質や付随条件を何一つ維 持寸ることができるものではないのである。その存在は寸べて頭の中

67 原始的共同体は消極的共同体であるとするプーフェンドルフの主張に関しては、 S. Pufendorf, De Jure Naturae et Gentium Libri Octo (1672; translation of 1688 ed. by C.H. and W.A. Oodfather, New York, London, 1964), IV. 4. 3. を参照。

68 ブラックストーンは、占有とは「それ以前には誰にも帰属していなかった物を所 持する行為」であると指摘する。Sir William Blackstone, Commentaries of the Laws of England (1765; 1783 ed., reprinted by Garland Publishing, New York, London, 1978), Book II, Chapter 16, 258.

6998 E.R., at 230 
にあるのみである70。

イェーツ裁判官の議論のより核心的な部分は、アイディアは万人に開か れたものであるということを明確に前提としているところにある。アイデ イアの性質はまさに、いったん公表されると、もはやそれらは独占的に使 用したり享受したりすることができないというものである。公表という行 為は、必然的に「公衆への贈り物」であり、そうしたアイディアはコモン ズに加えられる 71 $^{11}$ 。しし、以上のことから、著作者は自己の労力に対す る報酬を受ける資格がないということにはならない。イェーツ裁判官は、 すべての者は自己の労働の成果に対する権利を取得するという原理を援 用して、著作者は報酬を受ける権利をもつということに賛同する。しかし、 この報酬は「人間の一般的権利、および財産の一般的ルール」を前提とし なければならないと説く ${ }^{72}$ 。

イェーツ裁判官は、自然法原理を巧妙かつ興味深い方法で利用寸る。ま さに人的財産法が自然法原理を基礎としているために、コモン・ロー上の 文芸的財産権は存在しえないのである。イェーツ裁判官によれば、財産権 は現実の占有に基礎をおくものであるが、abstract objects は占有すること ができない73。イェーツ裁判官がその判決の末尾で明らかにしているよう に、そのような [占有しえないものに基礎をおいた］権利が存在するとい

\footnotetext{
${ }^{70}$ Id., at 233 .

${ }^{71}$ Ibid.

${ }^{72}$ Ibid.

${ }^{73}$ Id., at 230. 占有の概念は、グロティウスとプーフェンドルフのいずれにとっても、 私的所有権の発生についての説明の当否を決する重要なポイントであると考えら れている。グロティウスの次の一節が、まさにその例証となっている。「財産ない し所有権が考案されたとき、自然界の状態を手本にして財産に関する法が制定され た。身体的な必要性に関連して財産という概念の使用が開始されたことが、前述し たように、財産の最初の起源であるのだが、それと同様の関係に基づいて、物が個 人の財産であるということが決定された。この関倸こそが『占有』と呼ばれるもの であり、それは、かつては共有物として保持されていた物に対する用語として最も 適切なものである。 H. Grotius, Mare Liberum (1608; R. Van Deman Magoffin tr., New
} York, 1916), 25 を参照。
う主張は、財産権の一般理論とは全く相容れないものである。確かに、正 義は著作者が何らかの報酬を受けるべきことを要求するが、議会は著作者 に有限期間の独占を与えるアン法を立法化したことで、正義の要請を満足 したのである。独占の付与は、それが正義と一致し、学問および科学を奨 励することから正当化される。しかし、この独占権の行使は、それが他者 の自然権と両立しなければならないという、最優先の条件の制約を受ける。 他者はアイディアを利用する権利を有しているのであり、独占権の対象物 を取引する権利を有しているのである。イェーツ裁判官の説示に暗示され ている共同体の考え方は、アストン裁判官の分析にみられるような強い消 極的共同体概念ではない。 abstract objects は、依然として万人が使用する 資源であり続ける。それらは、万人がアクセスして使用する自然権をもつ コモンズの一部となるのである。

Millar v. Taylor 事件は、少なくとも 2 つのレベルにおいて啓発的な裁判 例であることがわかる。1つのレベルでは、本件においてみられる、コモ ン・ロー上の著作権の存在を正当化する 3 つの異なった論拠が、現代的な 関連性を有している点である。ウィレス裁判官のインセンティヴの議論は クリエイティビティに対する動機づけは abstract objects に対する財産権を 利用寸ることによって高められ、そうした財産権がない場合には弱められ ると考える、現代経済学の議論の先駆けである ${ }^{74}$ 。アストン裁判官の自然 権による正当化は、一部の現代リバタリアンが主張する私的所有権の正当 化根拠に類似した立場である ${ }^{75}$ 。もう 1 つのレベルでは、本件は次のこと を明らかにした。すなわち、財産権に関する一階（first order）の正当化の 分析がたどる可能性の高い進路は、その分析が含まれる形而上学のスキー ムに深く依存しており、また共同体についての特徵や前提に特に依存して いるということである。この依存関係があまりにも強いため、自然法とい う同じ一階の道徳理論の枠内であっても、共同体についての見方が異なれ ば特定の財産権の取決めを正当化しうるか否かについての結論が異なっ てくるのである。

74 財産権の重要性一般については、D.C. North and R.P. Thomas, The Rise of the Western World: A New Economic History (Cambridge, 1973) を参照。

${ }^{75}$ R. Nozick, Anarchy, state, and Utopia (Oxford, 1974). 
コモン・ロー上の著作権に関する初期の裁判例が抱える 1 つの難問は、 それらが発寸る明らかに矛盾したシグナルである。ホールズワースが指摘 するように、ほとんどの英国裁判官はコモン・ロー上の著作権を支持した が、それにもかかわらず英国法においては最終的に経済的で実用的な著作 権法概念が勝利したのである76。なぜこうしたことが生じたのかという問 題について研究を行う価值は十分にある。ともあれ、ロック流の自然権を 基礎と寸る財産権の説明は、18世紀のイングランドにおいて広く受け入れ られたのである ${ }^{77}$ 。大多数の英国裁判官は、その出発点として、個人の労 働と私的所有権の存在との強い関連性、つまり自然法の伝統を引き継ぐ理 論家がこれまで議論してきた関連性を前提とする見解をとった。Jefferys v. Boosey 事件においてポロック裁判官が提唱したような、著作権は「全く人 工的な権利」であるという見解をとった裁判官の数は極めて限られていた のである ${ }^{78}$ 。

著作権法の経済的概念はおそらく、自然法原理に反してというよりも、 むしろ自然法原理のおかげで英国法に到来した。営業を行う万人の権利は、 長い間コモン・ローの一部を形成し、他の大方の権利よりも基本的な地位 を享受してきた ${ }^{79}$ 。コモン・ロー上の著作権の問題について解決を迫られ た裁判官は、文芸的財産権による永久の独占がもたら寸経済的影響を考慮 せざるをえなかった。彼らは、出版者と著作者の利益を分離するのではな く、アン法の施行を支持することによって、潜在的には絶対的なコモン・

${ }^{76}$ W.S. Holdsworth, A History of English Law (2nd ed., 1937, London), vol. 6, 379 を参照。 米国についても同じことがいえる。米国では、Wheaton v. Peters, 33 U.S. (8 Peters) 591 (1834)において連邦最高裁がコモン・ロー上の著作権を廃止した。

77 ロックの影響に関しては、R. Larkin, Property in the Eighteenth Century (Dublin, Cork, 1930) を参照。

${ }^{78} 4$ H.L.C. 815,10 E.R. 681 at 729

79 営業の自由（取引の自由：freedom of trade）の権利は、Millar v. Taylor 事件の中で イェーツ裁判官によって自然権として描かれている。9 8 E.R. at 250 参照。本章にお いて後述する The Case of Monopolies もこのような見解にとっての典拠となる。この 原則の基本的性質を説く他の裁判例としては、The Case of the Tailors, etc. of Ipswich (1614) 11 Co. Rep. 53a, 77 E.R. 1218 やNorris v. Staps (1616) 11 Co. Rep. 53a, 80 E.R. 357 がある。
ロー上の著作者の権利を制限する道を選んだのである ${ }^{80}$ 。また、著作権に 対する経済的見地の勝利は、変化する経済的、技術的状況に適合した現実 的な解決策を作りだすために自然法上の財産原則の調整がいかにして行 われたかを示寸、1つの例であるということもわかる。英国法は、著作権 の経済的概念を採用寸るに際して、実際に自然権的正当化を否定したわけ ではない。むしろ英国法は、自然法原則を採用したうえで、著作者が自己 の労働に対して一定の報酬を獲得する一方、他者もまた自己の営業の自由 に対する自然権を追求しうるよう取り計らう、そのような現実的な解釈を 自然法原則に与えたのである。そしてそれは結局、拡大の一途をたどった 18世紀後半の産業経済に適合する解釈であったのである。

\section{特許権}

意義深いことに、発明者は著作者と同様に永続する権利を享受すべきで あるという議論が真剣になされたことはなかった。発明者の権利が国王大 権や議会制定法に依拠するものであるということは定着していた ${ }^{81}$ 。この 理由はおそらく、発明は社会的有用性の観点から非常に重要なものとして 考えられていたため、発明者の手に委㸚ておくことができなかったからで あろう。コモン・ロー上の文芸的財産権を支持した裁判官は、発明に対寸 る財産権と書籍に対する財産権との区別を図るという課題を抱え込むこ とになった ${ }^{82}$ 。これは難しい分析上の仕事である。というのも、発明と著 作の双方とも精神の労働をともなうからである。一方の労働は国家が特許 という形で特権の付与を決定しない限り、何の権利も確立しないのに対し て、なぜ他方の労働は自然権的財産権を確立すると考えるべきなのであろ うか。英国法が採用した哲学的な解答は、発明者は単に既存の物を発見す るにすぎないのに対して、著作者は何かを生みだすからである、というも

${ }^{80}$ 出版者と著作者の利益を切り離して考える必要があることについては、L.R. Patterson, Copyright in Historical Perspective (Nashville, 1968) を参照。

${ }^{81}$ Jefferys v. Boosey (1854) 4 H.L.C. 815, 10 E.R. at 745.

82 若干の試みとして、Millar v. Taylor 98 E.R. at 216 and 226 を参照。 
のである ${ }^{83}$ 。この解答は、特に説得的であるわけではない。発明者は何も 生みださないという発想は、自然法則の先在とその新たな応用とを混同し ている。後者の行為は実際に創作的労働を必要とする。発明に創作的要素 が存在するにもかかわらず、英国法は依然として、特許権の取扱いにおい て高度に道具主義的であったといえる。特許権は何世紀にもわたり、特権 という言葉から決して離れることはなかった。このことが著作権について も当てはまるのかどうか [著作権もまた特権であるのかどうか］に関して は、さらに多くの司法上の反対が存在したが、最終的には著作権も特許権 と同様に、自然権ではなく特権であると考えられるようになった。

特許法は、著作権法と同様、中世イングランドにおける国王大権に基づ く特権制度に起源を有する。国王は、特権付与に関する国王大権に基づい て、土地の利権、多様な公職、一手販売権（franchises）の付与を含むあら ゆるものを付与しえた。こうした特権付与の権限の範囲は広範なもので女 ったが、独占権の付与に関しては慎重に行われなければならないというの が建前であった。問題は現実にはそうならなかったことであった。代々の 英国国王にとって、独占権の付与は都合のよい収入源となった。ホールズ ワースは、国王が理論上は制限された独占権付与の権限を巧みに利用して 金儲けを行う姿勢を適切に描写している。

ジェームズ I 世 (James I) は絶えず財政難に喘いでおり、対価を目当 てに、政府関係および産業関係の双方について多数の特権を付与する 用意をしていた。…ㄷうこしたさまざまな特権付与のうち後者の産業 関係の例として、牛革の輸出に関する独占権の付与、タラとリングの 輸入に関寸る独占権の付与、ファージング銅貨の製造に関する独占権 の付与等を挙げることができる ${ }^{84}$

83「もしミルトン (Milton)が『失楽園』(Paradise Lost) を書かなかったならば、それ は永遠に現れなかっただろう。もしワット（Watt）が高圧蒸気利用について発明を しなかったとしても、ほかの誰かがそれを発明しただろう。」Halsbury, The Laws of England (London, 1912), vol. 22, p.127, para. 267 を参照。

${ }^{84}$ W.S. Holdsworth, 'The Commons Debates 1621', 52 Law Quarterly Review, 481, 487 (1936).

50 知的財産法政策学研究 Vol. 34 (2011)
国王に上る独占権付与の権限行使が非常に慎重になされなければなら なかった理由は、The Case of Monopolies が明らかにしたように、権限自体 がかなり制限されたものであったからである。国王大権が、理想の観点か ら国民の消極的自由の保護を意図したマグナ・カルタおよびコモン・ロー の制約を受けていたことは明らかであった ${ }^{85}$ 。国王大権に基づく独占権は、 各国民がある種の営業を行うことを完全に妨げることから、消極的自由に 対する著しい干渉であった。伝統的な財産権は、取引や営業を行う過程で 蓄積された財産保有を保護するように機能したことから、消極的自由に対 する同様の危険を抱えることはなかった。伝統的な財産権は、他者が取引 や営業を行うのを妨げたりしなかった。

コモン・ロー裁判所が独占権付与に対して示した反応は、たとえ契約の 自由への干渉となるような場合でも、営業の自由（freedom of trade）の原則 を最重要視するというものであった ${ }^{86}$ 。しかしながら、裁判所は、国王大 権行使の有効性を判断する司法権を有していなかったため、独占に関する 法宣言の機会を待たなければならなかった 87 。裁判所は、1601年に発布さ れた女王の詔勅によって、独占に関する問題を取り扱う司法権を与えられ た。そして翌1602年、英国法上最も有名な事件の1つである The Case of Monopolies が、女王座部裁判所で審理された ${ }^{88}$ 。この裁判例のストーリー はこれまでも頻繁に語られてきた ${ }^{89}$ 。本書は、本件において、若干の例外 はあるが独占はコモン・ローに違反する、という結論を支持する際に用い られた議論に関心がある。

85 コモン・ロー上の営業の自由を宣言した初期のケースとして、The Case of Mo nopolies, 77 E.R., at 1263 において言及された、Davenant v. Hurdis (1599) がある。

${ }^{86}$ Nordenfelt v. Maxim Mordenfelt Guns and Ammunition Company [1894] A.C. 535, per Lord Watson at 552 を参照。このほか、Trego v. Hunt [1896] A.C. 7, per Lord Macnaghten at 24 も参照。

${ }_{87}^{87}$ K. Boehm, The British Patent System, I: Administration (Cambridge at the University Press, 1967), 15 を参照

${ }^{88}$ (1602) 11 Co. Rep. 84b, 77 E.R. 1260. 本件はまた、Darcy v. Allen (1602) Noy 173, 74 E.R., 1131; Darcy v. Allen (1602) Moore K.B. 671, 72 E.R. 830 としても記録されている。 ${ }^{89}$ W.S. Holdsworth, A History of English Law (2nd ed., 1937, London), vol. 4, 349-353 を 参照。 
本件は、ダーシー (Darcy) が、イングランドにおいてトランプの供給を 行う排他権、とりわけトランプの輸入、販売を行う排他権を付与寸る特許 状を取得したことに関係するものである。ダーシーは、アレン (Allen) が トランプを無断で販売し、自己の特許権の利益を詐取したと主張して、ア レンを訴えた。原告ダーシーの独占は望ましいものであるのか否かという 一般的な問題について、被告アレンの弁護士が陳述した弁論の中には、判 決に取り入れられた主張がいくつか存在した ${ }^{90}$ 。その 1 つは、雇用に関係 するものであった。他者の労働を妨げる独占権は王国の利益に反するもの である。コモン・ローにおいて、すべて国民は適法な営業を行う権利を有 している ${ }^{91}$ 。う 1 つ弁論は、端的に経済的なものであった。独占権は 究極的には私的利益を目的としており、これは独占権が一定の望ましくな い性質を有していることを意味する。とりわけ、独占権は価格の高騰を招 くものである。また、いったん独占権がほかの誰かに付与されると、もは や当該営業を営むことができなくなることから、独占権はその付与前には 当該営業を営むことができた人々の暮らし向きを悪くしがちである。コモ ン・ローおよび「エクイティとしての神の法」はともに、こうした独占権 の性質を非難するものである ${ }^{92}$ 。

本件における 1 つの明確かつ重要な主題は、独占権は国民の営業の自由 に対する重大な干渉であり、そうした理由からコモン・ロー上無効である、 というものである。特権を設定する国王大権が、国民を苦しめるために行 使されることは許されないだろう。アレンの弁護士は、独占特許の有効性 に関して 1 つの例外が存在すると主張した。ある個人が有用な商業や発明 を王国内に導入する場合には、「国王は、当該発明によって王国内にもた らされる利益に鑑みて、国民が同様の発明を習得するまでの合理的な期間、 彼に独占特許を付与寸るだろう。しかし、それ以外の場合には独占特許を

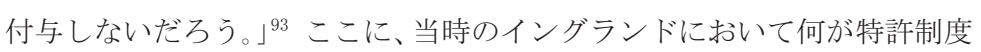

\footnotetext{
90 被告側の弁護士が陳述した弁論については、Noy 173, 74 E.R. 1131 に記録されて いる。

9177 E.R., at 1263 を参照。

${ }^{92}$ Id.

9374 E.R., at 1139
}

の目的であると認知されていたかということに関する明確な指標が存在 する。つまりそれは、価值ある商業や技術をイングランドに導入すること を奨励するというものであった。国王は、国王大権を適切に行使している と寸れば、何かを発明した者や外国から発明や商業を導入した者に対して のみ独占権を付与寸るであろう 94 。たがって、発見行為のみならず、外 国で発見された物を輸入する企業家の活動に対しても、この段階において 恩恵が与えられていたのである。特許制度の重要な目的は、実際のところ、 人的資本の発展を促進することであった。ただし、いったん関連した知識 が社会全体に普及すると、独占権は商業を阻害することになるため、国王 は独占権の更新を行うことができなかった ${ }^{95}$ 。

以上のような特許制度の道具主義的正当化のほかにも、独占権の役割を 制限する理由をもたらす、宗教上の道徳性に基づく重要な論法が存在する。 被告アレンの弁護士は、訴訟において、本件独占権は神の法に反するもの であるということを論証しようとした。その主張は、次のようなものであ った。自己や自己の家族が生き残るために労衔をするということは神の命 令である。人間の労働はさまざまな営業技術を生じさせるが、これは神の 構想の一部である。そのため、自ら選択した営業を営むことを禁止するも のは、すべて自由への干渉であるだけでなく、神の法の侵害でもある。以 上の主張は、簡潔に述べられているが、これまでにない強い口調で独占権 を非難してきた教会の教えを利用していることから、おそらくは裁判所の 聴衆に対して相当の説得力を有したと思われる。教会が多くの独占権を罪 とみなしてきた理由は、いくつか存在した ${ }^{96}$ 。独占権保有者の価格決定能

94 このことを明確に述べるものとして、The Clothworkers of Ipswich Case (1615) Godbolt, 252, 78 E.R. 147 を参照。初期の特許に課された一定の訓練条件については、 E.W. Hulme, 'The History of the Patent System under the Prerogative and at Common Law’, 12 Law Quarterly Review, 141-154 (1896) を参照。

${ }_{95}$ The Clothworkers of Ipswich Case (1615) Godlbolt, 252, 78 E.R. 147.

96 宗教の思想や倫理が商取引に及ぼした影響についての古典的だが一般的な記述 として、R.H. Tawney, Religion and the Rise of Capitalism (West Drayton, Middlesex, 1938 ed.)がある。このほか、D.J. Gerber, 'Prometheus Born: The High Middle Ages and the Relationship Between Law and Economic Conduct', 38 Saint Louis University Law Journal, 673, 720-725 (1994) も参照。 
力は、公正な価格理論に反するものであった ${ }^{97}$ 。独占権は、投機的経済的 な性質を有寸るものとみなされ、高利貸しに向けられた道徳的批判一般の 対象となった。また、多数の独占権は食糧と関係するものであった。その ため、必需品の不足を生みだす独占権保有者の能力は、公共の福祉の一部 とはなりえないと考えられていた。

独占権は神の法に違反するという議論は、労働を最重要なものとして位 置づける。キリスト教社会では、他者の労働は特許権の役割の不要な設定 や拡大を防止する理由となる。特許権は、他者の労働に干渉するからこそ、 特権なのである。特許権の設定は、他者の労働権と調和しなければならな い。被告アレンの弁護士が主張したように、人間の労働能力は神の構想の 一部なのである。特許権はこうした神の構想に干渉する可能性があるため、 特許権の設定権限を有寸る者が誰であれ、責任をもって行動しなければな らない。（特許権の設定に用いられた）国王大権は、「国民を害寸る正当な 理由となるものではない」のである ${ }^{98}$

コモン・ロー裁判所の独占権に対するアプローチの中核を担う道具主義 的態度は、1623年の専売条例へと進んでいった。専売条例の第 1 条は、「公 共財」(publique good）の普及を促進するという意図された役割を独占権が 果たしてこなかったことを明らかにし、したがって、すべての独占権はこ の王国の法に反し、無効であると宣言した。ただし、例外が 1 つあり、第 1 条の宣言は新しい製造方法の発明者に対する特許付与には及ばないとさ れた ${ }^{99}$ 。特許の付与は、それが法に反寸るものではないこと、あるいは、 何らかの形で「国家に害を与える」ものではないことを条件とした。専売 条例は、特許が自然権といった類のものではなく、特権として発明者に帰 属するものであることを明確にした。そして、その第 1 条において、独占 がこの王国の「古くからある基本法」(auncient and fundamental lawes）に反 するものであることを明記したのである。これは、かりに独占権が許容さ れるとすれば、公共財の普及に貢献する場合に限られるということを含意

971 つの説明として、R. De Roover, 'Monopoly Theory Prior to Adam Smith: A Revision', 65 Quarterly Journal of Economics, 492, 500 (1951) を参照。

9874 E.R., at 1139

${ }^{99}$ Section 6.
している。専売条例は多くの点で経済政策を純粋に反映したものであっ た ${ }^{100}$ 。

立法府が特許権を自然権という用語で表現するのを躊躇った理由は、国 王による特権制度の濫用という観点から完全に理解できる。自然権概念が 革命期に政治的影響力を発揮していた米国やフランスのような諸国にお いてでさえ、自然権が特許権に及ぼす影響力の程度は、これらの法域にお ける初期の特許法を基準に考えれば弱まってきたように思われる。自由権 のような古典的な自然権には権利の有効期限があるとは考えられていな かったが、米国やフランスでは、特許権は当初から実定法によって容易に 創設され、制限され、そして最終的には消滅される可能性のある権利とし てみなされていたのである101。

\section{結 論}

ここまでの考察により、英国法においてなぜ特許権の正当化がこれほど 高度に道具的であったのか、また一定の議論の後、なぜ著作権も同じ道を 歩んだのかという点について、理解がより容易になったといえよう。個人 は自己の労働によって生きていかなければならないということは、当時の 社会においては論争の対象にならなかった。これは神の構想の一部であっ た。発明者や著作者は他者と同様、労働をして報酬を得る権利を有してい たが、神の構想と整合を図る形で彼らに認められた報酬は一時的な特権に 寸ぎなかった。これ以上のものは、他者の労働に対する過度の干渉となり、 したがって神の法や英国の基本法に反することになるだろう。発明者や著 作者はせいぜい他者に対してある種の一時的な優越を期待しえたにすぎ ない。この優越の性質が特権なのであった。そうした特権はそれ以上のも

100 W.R. Cornish, Intellectual Property (2nd ed., London, 1989), 67.

101 初期の米国特許法に関する議論については、B.W. Bugbee, Genesis of American Patent and Copyright Law (Washington, D.C., 1967) を参照。また、フランスの1791年 の特許権に関する国民議会デクレは、自然権という言葉を用いる一方で、発明者の 思想が有用であることを要求し、かつ当該権利の保護を特定の期間に制限するもの であった。Bugbee at 153 を参照。 
巻頭論文

のとはなりえなかった。なぜなら、そのことは、特に商取引分野において 他者の消極的自由を過度に劦か寸ものであると解されるからである。営業 の自由の権利はコモン・ロー上の基本的権利である。それは少なくとも理 論上は、人々が労働力に参入する権利を有していたということを意味する。 abstract objectsに対する一時的な特権は他の人々の産業を増大させる長期 的な効果をもつと考えられた。そうした特権は基本法や神の構想と整合的 なものであった。しかし、 abstract objectsに対する自然権的財産権はそれ らと整合性がとれるものでは決してなかった。人の労働が生みだした physical objectsに対する自然権的財産権は神の構想と整合性がとれるもの であった。

特許権や著作権の道具的正当化の興味深い特徴は、そうした正当化が自 然法の伝統の文脈において、つまり一見すると人の労働の精神的成果物を 道具的に取り扱うことを支持するようには思われない伝統の文脈におい て行われたということである。そのような正当化が現れたということは、 知的財産権の正当化を行う場合、重要な選択は、一階の道徳理論の間（自 然法対功利主義）にあるのではなく、むしろ共同体概念とその共同体概念 が依拠している形而上学の体系との間にあるということを示している。偶 然にも、正当化根拠の問題についての現代の重点は一階の道徳理論のレ心゙ ルにおかれている。しかし、このことは共同体概念が正当化根拠の問題に 無関係であるということを意味しない。むしろそのことは、共同体概念が 正当化根拠をめぐる議論を静かに操作しているということを示唆してい るのである。 